University of Wisconsin Milwaukee

UWM Digital Commons

Theses and Dissertations

August 2013

\title{
Habitat Matters for Inorganic Carbon Acquisition in 38 Species of Red Macroalgae (Rhodophyta) from Puget Sound, Washington, USA
}

Maurizio Murru

University of Wisconsin-Milwaukee

Follow this and additional works at: https://dc.uwm.edu/etd

Part of the Ecology and Evolutionary Biology Commons

\section{Recommended Citation}

Murru, Maurizio, "Habitat Matters for Inorganic Carbon Acquisition in 38 Species of Red Macroalgae (Rhodophyta) from Puget Sound, Washington, USA" (2013). Theses and Dissertations. 259.

https://dc.uwm.edu/etd/259

This Thesis is brought to you for free and open access by UWM Digital Commons. It has been accepted for inclusion in Theses and Dissertations by an authorized administrator of UWM Digital Commons. For more information, please contact open-access@uwm.edu. 


\title{
HABITAT MATTERS FOR INORGANIC CARBON ACQUISITION IN 38 SPECIES OF RED MACROALGAE (RHODOPHYTA) FROM PUGET SOUND, WASHINGTON, USA ${ }^{1}$
}

\author{
by \\ Maurizio Murru \\ A Thesis Submitted in \\ Partial Fulfillment of the \\ Requirements for the Degree of \\ Master of Science \\ in Biological Sciences
}

at

The University of Wisconsin-Milwaukee

August 2013 


\begin{abstract}
HABITAT MATTERS FOR INORGANIC CARBON ACQUISITION IN 38 SPECIES

OF RED MACROALGAE (RHODOPHYTA) FROM PUGET SOUND, WASHINGTON, USA ${ }^{1}$
\end{abstract}

by

\title{
Maurizio Murru
}

The University of Wisconsin-Milwaukee, 2013

Under the Supervision of Professor Craig D. Sandgren, and John A. Berges (Acting)

The ability of macroalgae to photosynthetically raise the $\mathrm{pH}$ and deplete the inorganic carbon pool from the surrounding medium has been in the past correlated with habitat and growth conditions. The objectives of this study were 1) to test for differences among a variety of red algal species in their ability to deplete the dissolved inorganic carbon pool (DIC) from the surrounding medium, and to utilize the $\mathrm{HCO}_{3}{ }^{-}$fraction of the DIC, 2) to determine whether these differences were associated with red algal habitat defined as intertidal height and subtidal depth, and/or with taxonomic affinities of the species studied (taxonomic order or family), and 3) to investigate possible within-species differences in DIC acquisition abilities in Mastocarpus papillatus, a species with a wider vertical distribution within the intertidal. No attempts were made to identify the specifics of the mechanisms used by macroalgae for dissolved inorganic carbon uptake.

Measurements of pH drift were used to measure the ability of 38 red algal seaweeds to utilize bicarbonate and to deplete the DIC from seawater medium. Subtidal algae were typically restricted to the use of DIC in the form of dissolved $\mathrm{CO}_{2}$, reducing the initial DIC by only $9 \%$. Intertidal species used both dissolved $\mathrm{CO}_{2}$ and bicarbonate, 
and reduced initial DIC by as much as $70 \%$. DIC reductions and $\mathrm{pH}$ compensation points for the intertidal species tested were strongly correlated with their vertical zonation on the rocky shoreline. The efficiency in DIC depletion from the medium generally increased with tidal height, but species from the upper edge of the intertidal reversed the trend and demonstrated significantly lower DIC depletion abilities. This general pattern associated with tidal height was observed, not only among intertidal red algal species in general, but also among four species of the genus Porphyra (P. torta V. Krishnamurthy, $P$. papenfussii Krishnamurthy, P. perforata J. Agardh, P. fucicola Krishnamurthy) and among four populations of the broadly distributed species Mastocarpus papillatus (C. Agardh). The Mastocarpus observations suggest either that individuals of this species may be able to express alternate strategies for carbon acquisition, or that intertidal height may select for survivorship of genotypes with different carbon acquisition strategies. The four species of Porphyra were consistently less efficient in depleting the DIC from the medium than other macroalgal species from the same tidal height, providing the only evidence for a possible taxonomic effect on carbon acquisition. The physiological differences in DIC depletion from the medium were otherwise not related to phylogeny, tested as membership in red algal families and orders.

This work suggests that the carbon acquisition strategy found in red macroalgal species may be a physiological attribute that bears important ecological and evolutionary implications. 


\section{TABLE OF CONTENTS}

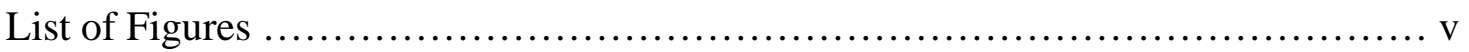

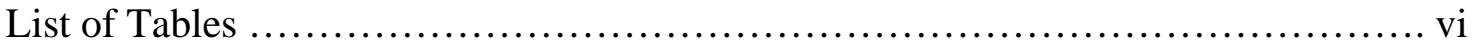

List of Abbreviations .......................................................... vii

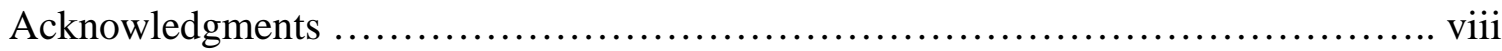

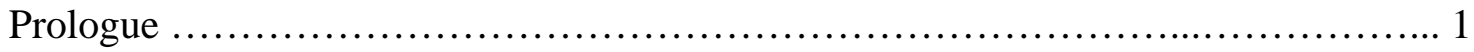

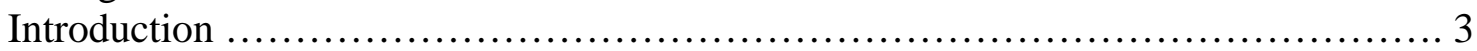

Carbon Utilization by Seaweeds

Carbon Concentrating Mechanisms

pH Drift Technique

Objectives

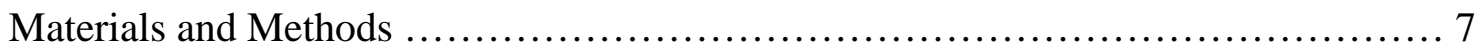

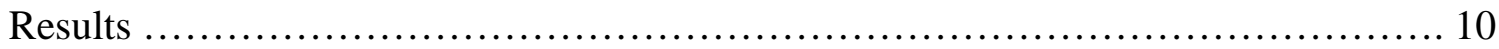

Extent of DIC Utilization

Correlations to Red Algal Taxonomy

Correlations to Habitat - general findings

Habitat effects among Porphyra species and Mastocarpus papillatus populations



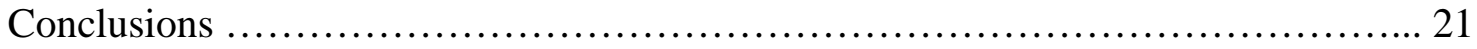

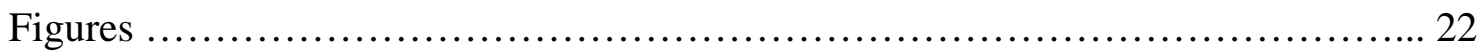



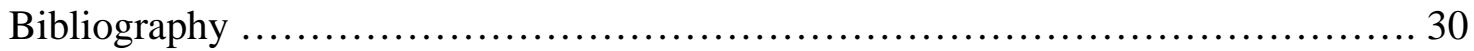

Final Conclusions and Second Thoughts ....................................... 36

Table 3: Citation Analysis Table ................................................... 43

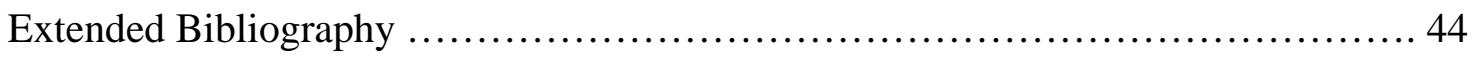




\section{LIST OF FIGURES}

Figure 1 - pH Compensation Point and Residual DIC ............................. 22

Figure 2 - Average pH Compensation Point and Residual DIC by Species ............. 23

Figure 3 - Average pH Compensation Point and residual DIC for Porphyra species .... 24

Figure 4 - Average pH Compensation Point and residual DIC for M. papillatus ........ 25 


\section{LIST OF TABLES}

Table 1 - Nomenclature: Alphabetical List of Species Included in This Study ........ 26

Table 2 - Summary of Species Habitat, pH Compensation Point and Residual DIC ... 28

Table 3 - Citation Analysis Table ............................................ 43 


\section{LIST OF ABBREVIATIONS}

CCM, Carbon Concentrating Mechanisms

DIC, Dissolved Inorganic Carbon

extCA, external Carbonic Anhydrase

MLLW, Mean Lower Low Water

NSW, Natural Seawater 


\section{ACKNOWLEDGMENTS}

I am grateful to the kind members of the Graduate Advisory Committee, Erica B. Young, John A. Berges, and Harvey A. Bootsma for their patience, help and constructive feedback and to Rudi J. Strickler for his earlier encouragement and suggestions. I would like to thank the University of Washington, Friday Harbor Laboratories, and the former Director of the laboratories, Dr. A. O. Dennis Willows, for kindly providing research space and support. Special thanks go to Prof. John A. Raven for his editorial insight and valuable annotations during the publication phase of this work. 


\section{PROLOGUE}

The distinct and somewhat predictable vertical distribution of macroalgae has triggered much research and a wealth of publications regarding its ecological and physiological causes. I was not immune to the intrigues of the system especially with respects to the multifaceted aspect of inorganic carbon acquisition. What created the basis for a personal and genuine interest in the topic were the readings, in the late $90 \mathrm{~s}$, of journal articles describing methods for investigating the abilities of macroalgae to deal with inorganic carbon acquisition, and to explore physiological characteristics that could be translated into ecological adaptations or constraints. Among the various methodological approaches, the $\mathrm{pH}$ drift technique intrigued me the most, for its simplicity and inherent methodological reliability (see for example Allen and Spence 1981, Maberly, 1990, Maberly and Madsen 2002, Snoeijs et al. 2002).

More than the intrinsic physiological mechanisms of inorganic carbon acquisition, I was interested in the overall ecological patterns of the mechanism, and its relationship to taxonomy, habitat and the inherent environmental constraints. I felt that many of the publications on the topic did not incorporate two aspects: 1) a comparative analysis of a wide variety of species where taxonomic relationships could have helped explain physiological and ecological aspects of carbon acquisition and 2) a careful analysis of within-species carbon acquisition characteristics for those macroalgae that have a broader vertical distribution. When the research plan took shape and decisions had to be made regarding logistics and location, we chose to include the red macroalgal flora spanning from the upper fringes of the intertidal to the lower subtidal. The rationale was based 
upon the fact that Rhodophytes seem to have a variety of DIC acquisition abilities, and to include some of the best known examples of species for which no CCMs have been found (see for example Beer 1999, Giordano et al. 2005, Raven et al. 2005). This decision allowed us to include four Porphyra species (see table 1) and Mastocarpus papillatus (C. Agardh) Kützing. Each of the four species of Porphyra is found within a separate, narrow and discrete vertical band in the upper intertidal, and although recent taxonomic work and latest DNA Barcodes puts them into two different genera, Pyropia and Fuscifolium (see table 1 for more information, and Sutherland et al. 2011), they represented an opportunity to investigate possible differences in DIC acquisition among closely related species. The relatively broad vertical distribution of Mastocarpus papillatus (C. Agardh) Kützing allowed us to investigate the occurrence within a species (and population) of differences in inorganic carbon acquisition strategies, suggesting possible ecological and/or evolutionary causes of this important physiological aspects.

The research took place in San Juan Island, Puget Sound, WA, at the Friday Harbor Laboratories over the span of few summer months, in 1997, 1998, 2000 and 2001. The present work led to an article that was submitted to the Journal of Phycology in October 2003 and was accepted in July 2004. The article was published as Murru, M. \& Sandgren, C. D. 2004. Habitat matters for inorganic carbon acquisition in 38 species of red macroalgae (Rhodophyta) from Puget Sound, Washington, USA. Journal of Phycology, 40: 837-45. 


\section{INTRODUCTION}

Carbon dioxide concentrations in seawater are similar to those in air, but in aqueous solution in natural seawater (NSW), $\mathrm{CO}_{2}$ becomes part of a buffer system in which the component chemical species, dissolved $\mathrm{CO}_{2}, \mathrm{H}_{2} \mathrm{CO}_{3}, \mathrm{HCO}_{3}{ }^{-}$, and $\mathrm{CO}_{3}{ }^{2-}$, are in equilibrium. The relative amounts of these fractions of inorganic carbon at equilibrium are dependent on salinity, temperature and $\mathrm{pH}$ values (Lobban and Harrison 1997). At the $\mathrm{pH}$ value of 8 typically found in NSW, the majority of the dissolved inorganic carbon (DIC), over $95 \%$, is present as $\mathrm{HCO}_{3}{ }^{-}$. The dissolved $\mathrm{CO}_{2}$ fraction of DIC is very small (about $10-13 \mu \mathrm{M}$ ) and transport is limited by slow diffusion rates, about 10,000 times slower in water than in air (Lobban and Harrison 1997).

\section{Carbon Utilization by Seaweeds}

Research has shown that, for many species of macroalgae, the maximum rate at which $\mathrm{CO}_{2}$ for photosynthesis can be supplied from the spontaneous dehydration reaction of bicarbonate is at times too slow to account for the measured rates of carbon fixation (Lucas 1983, Cook et al. 1988, Israel and Beer 1992, Mercado et al. 1998). In conditions where water movements are reduced and/or photosynthetic rate exceeds the rate at which $\mathrm{CO}_{2}$ is supplied, algal photosynthesis can therefore become inhibited by a lack of adequate $\mathrm{CO}_{2}$ supply. In these conditions, alternative mechanisms for inorganic carbon acquisition can become ecologically important and competitively advantageous.

All seaweeds utilize dissolved $\mathrm{CO}_{2}$ as the preferred substrate fueling the dark reactions of photosynthesis. Some species seem to be restricted to the passive diffusion 
of dissolved $\mathrm{CO}_{2}$ into the cells to fulfill their photosynthetic needs (Joliffe and Tregunna 1970, Kübler and Raven 1994). However, a large number of marine macroalgae have been described as using $\mathrm{HCO}_{3}{ }^{-}$as an alternative source of carbon for photosynthesis (Joliffe and Tregunna 1970, Beer and Eshel 1983, Sand-Jensen and Gordon 1984, Cook et al. 1986 and 1988, Giordano and Maberly 1989, Prins and Elzenga 1989, Larsson and Axelsson 1999, Mercado and Niell 1999). Axelsson and Uusitalo (1988) have suggested that most seaweeds are able to utilize $\mathrm{HCO}_{3}{ }^{-}$as a source of DIC, but the extent of its use varies among taxa. The differences in the extent to which $\mathrm{HCO}_{3}{ }^{-}$can be used are reportedly more pronounced for intertidal seaweeds than for subtidal species (Axelsson and Uusitalo 1988, Mercado et al. 1998, Snoeijs et al. 2002).

\section{Carbon Concentrating Mechanisms}

Any means that achieves $\mathrm{CO}_{2}$ concentrations at the site of RUBISCO in chloroplasts that are higher than what is attainable by passive diffusion of $\mathrm{CO}_{2}$ can be interpreted as a carbon concentrating mechanism (CCM) (Kübler and Raven 1994). Only dissolved $\mathrm{CO}_{2}$ can freely diffuse through the plasma membrane; other forms of DIC require direct or indirect active, i.e. energized, transport mechanisms (Lucas 1983, Kerby and Raven 1985, Prins and Elzenga 1989). A number of different mechanisms of inorganic carbon transport through the plasmalemma have been proposed (Lucas 1983, Price and Badger 1985, Raven and Lucas 1985, Prins and Elzenga 1989, Haglund et al. 1992, Badger and Price 1994, Raven 1997, Axelsson et al. 2000). These energetically 
expensive CCMs seem ecologically advantageous only when the photosynthetic organism is exposed to carbon limitation (Kübler and Raven 1994, Raven 1997).

The uptake by cells of any of the forms of DIC eventually results in a near stoichiometric production of hydroxyl ions (Lucas 1983, Cook et al. 1988, Israel and Beer 1992, Raven 1997). This causes an increase of $\mathrm{pH}$ in the boundary layer surrounding the algal thallus (Allen and Spence 1981, Maberly and Spence 1983, Prins

and Elzenga 1989). Marine algae that rely strictly on passive diffusion of $\mathrm{CO}_{2}$ should be unable to raise the $\mathrm{pH}$ of the boundary layer above 9 ; at this $\mathrm{pH}$ value dissolved $\mathrm{CO}_{2}$ is virtually absent, the uncatalyzed $\mathrm{HCO}_{3}{ }^{-}$dehydration process is very slow and its rate cannot account for the photosynthetic rates attainable by some algae (Cook et al. 1988, Maberly 1990, Johnston 1991, Johnston et al. 1992). Because dissolved $\mathrm{CO}_{2}$ represents such a small fraction of the DIC in this situation, total DIC concentrations are little affected by photosynthetic carbon utilization. On the other hand, if species are able to utilize $\mathrm{HCO}_{3}{ }^{-}$, the $\mathrm{pH}$ value in the boundary layer can reach considerably higher values and the concentration of DIC in the surrounding milieu can be drastically reduced. Measurements of $\mathrm{pH}$ drift through time in a closed system can therefore indicate the presence or absence of photosynthetic $\mathrm{HCO}_{3}{ }^{-}$uptake.

pH Drift Technique

The $\mathrm{pH}$ drift technique has been used in many studies to investigate DIC uptake by algae (Allen and Spence 1981, Maberly and Spence 1983, Hofslagare et al. 1985, Axelsson 1988, Axelsson and Uusitalo 1988, Cook et al. 1988, Prins and Elzenga 1989, 
Maberly 1990, Beer 1994, Uusitalo 1996, Flores-Moya and Fernández 1998, Andría et al. 1999, Granbom and Pedersen 1999, Choo et al. 2002, Maberly and Madsen 2002, Snoeijs et al. 2002). Results from $\mathrm{pH}$ drift experiments are ecologically relevant and provide an indication of physiological characteristics of the algae under investigation. The results are tightly correlated with the ability to utilize $\mathrm{HCO}_{3}{ }^{-}$and with the consequent reduction of DIC in the surrounding milieu (Hofslagare et al. 1985, Axelsson 1988, Cook et al. 1988, Prins and Elzenga 1989, Maberly 1990, Snoeijs et al. 2002).

\section{Objectives}

The objectives of this study were to: 1) test for differences among red algal species and populations in their ability to deplete DIC from the surrounding medium and to utilize the $\mathrm{HCO}_{3}{ }^{-}$fraction of DIC, 2) determine whether any such differences were associated with red algal habitat defined as intertidal height and subtidal depth, and 3) determine whether differing carbon utilization strategies were correlated with taxonomic affinities (red algal orders, families) of the species studied. No attempts were made to identify the specifics of the mechanisms used by macroalgae for dissolved inorganic carbon uptake. 


\section{MATERIALS AND METHODS}

All macroalgae were collected during late spring and summer by dredge, free diving or by hand at low tide around San Juan Island (WA) in northern Puget Sound. At collection, the depth or the tidal height above the mean lower low water (MLLW) was recorded. Of 38 total species, 13 were collected subtidally at depths of $-1,-5$, and $-20 \mathrm{~m}$. The other 25 species were collected in the intertidal on semi-exposed sites at tidal heights between $-0.5 \mathrm{~m}$ and $+1.5 \mathrm{~m}$ above MLLW. One species (Neorhodomela oregona) was collected in a series of tide pools situated at $+2.5 \mathrm{~m}$. Laboratory studies were conducted at the University of Washington's Friday Harbor Laboratories located on San Juan Island.

All specimens were kept in running seawater tanks and were used for $\mathrm{pH}$ drift trials within $48 \mathrm{~h}$ of collection from the field. Only healthy specimens without obvious epiphytes were used, and all specimens were carefully cleaned and rinsed in seawater before trials began. Specimens were put in a water-jacketed glass beaker with $100 \mathrm{~mL}$ of filtered-sterilized SW enriched as $\mathrm{f} / 2$ medium. A magnetic stirrer provided mixing of the medium during the trial in order to minimize stratification and guarantee homogeneity. Specimens received continuous illumination of about $350 \mu \mathrm{mol}$ photons $\bullet \mathrm{m}^{-2} \cdot \mathrm{s}^{-1}$ (halogen source) during the trials. Specimen size was adjusted to prevent self-shading and insure effective agitation of the medium. Constant temperature $\left( \pm 1^{\circ} \mathrm{C}\right)$ during each $\mathrm{pH}$ drift trial was maintained by a re-circulating water bath pumping chilled water through the glassjacket of the reactor. The reactor was tightly closed with a grease seal to avoid gas exchange with air during trials. $\mathrm{pH}$ was measured by a gel-filled glass electrode inserted through the cover of the reactor vessel. $\mathrm{pH}$ and temperature were recorded through time 
with ORION pH meters connected to a computer equipped with DataCOLLECT ${ }^{\mathrm{TM}}$ Windows Software (Thermo Electron Corporation).

Each drift experiment was terminated when the $\mathrm{pH}$ reached and maintained a stable value for at least $1 \mathrm{~h}$, defined here as the $\mathrm{pH}$ compensation point. This $\mathrm{pH}$ value represents the condition in which the dissolved carbon taken up by the alga equals the $\mathrm{CO}_{2}$ released by respiration and/or photorespiration into the medium. During the drift experiment in a closed vessel under constant illumination, the thallus is forced to use all its physiological resources in order to exploit the DIC in the seawater until it reaches the limits of its extraction capability. The $\mathrm{pH}$ compensation point reached at the end of the drift is a reflection of the macroalgal physiology and indicates the extent of its ability to scavenge DIC from the seawater (Allen and Spence 1981, Maberly 1990, Choo et al. 2002, Snoeijs et al. 2002). The potential negative effect of the increased $\mathrm{pH}$ per se on the thallus physiology was not evaluated in our experiments.

Following each $\mathrm{pH}$ drift trial, the specimen was extracted from the reactor beaker, the beaker was immediately closed to minimize $\mathrm{CO}_{2}$ exchanges at the air-water interface, and the medium was titrated through a small opening with $0.02 \mathrm{~N} \mathrm{H}_{2} \mathrm{SO}_{4}$ to estimate alkalinity and residual DIC (Gran titration; Stumm and Morgan 1981). Concentrations of DIC were calculated from $\mathrm{pH}$, alkalinity, salinity and temperature of the medium according to Stumm and Morgan (1981). The specimen wet weight was measured, and then the dry weight was determined after drying at $80^{\circ} \mathrm{C}$ for $24 \mathrm{~h}$.

Only those species for which at least two trials were run were considered in statistical analyses. Statistical packages used throughout the study were SYSTAT, Version 10.2 (2002) and STATISTICA Version 6.0 (StatSoft, Inc. 2001). An alphabetical 
list of the species collected and included in this work is found in Table 1. All species were identified using Gabrielson et al. (2000) and Abbott and Hollenberg (1976). The nomenclature follows Gabrielson et al. (2000). 


\section{RESULTS}

\section{Extent of DIC utilization}

The data collected in this survey demonstrated a wide range in the ability of red macroalgae to raise the $\mathrm{pH}$ and to deplete DIC from the surrounding medium. In general, we found very good agreement between replicates for all species (Table 2). The coefficient of variation for the $\mathrm{pH}$ compensation point of a species was never more than $2.8 \%$ and averaged $0.3 \%$ among all species. The relationship between the $\mathrm{pH}$ compensation point and the residual DIC remaining in the medium at the end of the drift is shown in Figure 1. The estimated residual DIC was significantly different from the theoretical DIC expected for any given $\mathrm{pH}$, assuming constant alkalinity (t-test, $\mathrm{df}=117$, $p<0.0001)$. Notably, the distribution of the residual DIC data points departed consistently from the theoretical expectations when species were able to raise the $\mathrm{pH}$ of the medium to a value greater than $\mathrm{pH}$ 10.1. Above this $\mathrm{pH}$ compensation value, the residual DIC was consistently below predicted values.

\section{Correlations to red algal taxonomy}

There was no evidence that the differences in carbon utilization strategy among species were associated with families or orders of red algae from this location. The results of analysis of variance were not significant when taxonomic order or family was entered as independent variables to explain the variability among species in either $\mathrm{pH}$ compensation point or the residual DIC of the medium at the end of a drift (one-way ANOVA; $\left.\mathrm{F}_{\text {family }}=1.21, \mathrm{df}=19, p>0.05 ; \mathrm{F}_{\text {order }}=1.17, \mathrm{df}=8, p>0.05\right)$. 
The 4 species of Porphyra (Bangiophyceae) were compared to all the other macroalgae (Florideophyceae) found within the same tidal heights (Table 2, Fig. 2 and Fig. 3). The class-level taxonomic grouping, with tidal height as a covariate, was significant in explaining either the $\mathrm{pH}$ compensation point or the residual DIC (ANOVA; $\left.\mathrm{F}_{\mathrm{pH} \mathrm{cp}}=23.1, \mathrm{df}=1, \mathrm{p}<0.001 ; \mathrm{F}_{\text {resDIC }}=28.5, \mathrm{df}=1, \mathrm{p}<0.001\right)$. The Porphyra spp. were not able to extract the DIC from the surrounding medium as efficiently, and did not reach $\mathrm{pH}$ compensation point values as high, as the Florideophyceae from the same tidal height. This represented the only statistically significant taxonomic effect found in the dataset.

\section{Correlations to habitat - general findings}

In order to examine the relationship between species habitat, measured as intertidal tidal height or subtidal depth, and the ability to deplete DIC from the surrounding medium, the mean $\mathrm{pH}$ compensation point data for all species were explored using cluster analysis. The result was a joining tree (clustering rule- Least Squared Loss; resulting Proportional Reduction in Error $=0.78$ ) which identified four clusters of species separated by habitat along a subtidal-intertidal height gradient. These habitats were identified as: subtidal (-1 to $-20 \mathrm{~m}$ MLLW), lower intertidal zone (-0.5 to $0 \mathrm{~m}$ MLLW, upper intertidal zone $(+0.5$ to $+1.5 \mathrm{~m}$ MLLW) and high intertidal pool $(+2.5 \mathrm{~m}$ MLLW). When species data were subsequently aggregated into these zonation categories, they demonstrated significant differences among all habitats in both the $\mathrm{pH}$ compensation point and residual DIC (one-way ANOVA; $\mathrm{F}_{\mathrm{pH} \text { compensation point }}=114$, $\mathrm{df}=4, p<0.001$; $\left.\mathrm{F}_{\text {residual DIC }}=41, \mathrm{df}=4, p<0.05\right)$. 
In this study, the subtidal species were unable to raise the $\mathrm{pH}$ above 9.3 (Fig. 2). The $\mathrm{pH}$ compensation points and the residual DIC from the three subtidal depths were not statistically different (ANOVA, $\mathrm{F}=2.8, \mathrm{df}=2, p>0.05$ ), therefore all the specimens collected from the subtidal depths were grouped for further analyses. The residual DIC of subtidal species averaged $1.985 \mathrm{mmol} \cdot \mathrm{L}^{-1}(\mathrm{SD}=0.163)$. This represented a small but significant average reduction of $9.3 \%(t-t e s t, d f=32, p<0.001)$ from the initial DIC concentration in trials (Fig. 2 and Table 2).

The species collected from the lower intertidal zone also constituted a fairly compact and distinct group with regards to their inorganic carbon utilization capability (Figs. 2). These red algae demonstrated an increased ability to scavenge DIC in comparison to the subtidal red algae, with an average $\mathrm{pH}$ compensation point of 9.54 and DIC reductions averaging 20\% from the initial values and ranging between $10 \%$ (Halymenia gardneri), and 25\% (Chondracanthus exasperatus) (Table 2, Fig. 2).

The overall ability of the red algae from the upper intertidal zone to raise the $\mathrm{pH}$ and to deplete DIC was varied greatly among taxa in these data (Fig. 2). In an extreme case, Neorhodomela larix reached a final $\mathrm{pH}$ value above 10.5 units and a DIC reduction of $70 \%$ from the initial concentration in the medium. The general trend among species is towards decreasing residual DIC with increasing tidal height from +0.5 to $+1.3 \mathrm{~m}$ (including Microcladia, Odonthallia, Halosaccion, Ceramium, Neorhodomela, three Mastocarpus populations), and then a dramatic reduction in DIC scavenging capabilities among the species from the upper extreme of the intertidal zone (Endocladia, Callithamnion, one Mastocarpus population). $\mathrm{pH}$ drift trials for those species in the first list, those with the highest $\mathrm{pH}$ compensation points and lowest residual DIC, resulted in a 
measured decrease in total alkalinity in the buffer solution suggesting a change in the ratio of bases and protons in the surrounding medium. Porphyra species (Fig. 3 and 4) demonstrated different carbon scavenging capabilities than other intertidal red algae and are considered separately (see below).

Neorhodomela oregona from high intertidal pools was among the most effective species in depleting the DIC from the medium, with a nominal decrease of $65 \%$ from the initial value associated with a $\mathrm{pH}$ compensation point of 10.2. This species also demonstrated a loss of alkalinity from solution during drift trials.

Habitat effects among different Porphyra species and Mastocarpus papillatus populations

Four species of Porphyra (P. torta, P. papenfussii, P. perforata, P. fucicola) were included in the data set. Although these Porphyra species were not as effective at DIC scavenging as other red algal species from the same tidal height, they adhered to the general multi-species trend documented with this survey (Fig. 2 and 3). P. torta from the high intertidal was unable to raise the $\mathrm{pH}$ of the surrounding medium to the same extent as were Porphyra species found lower in the intertidal. This was confirmed by one-way analysis of variance (ANOVA, $\mathrm{F}=11.55, \mathrm{df}=9, p<0.01)$ and Tukey Post-hoc comparison test.

Specimens of Mastocarpus papillatus were collected from four different tidal heights along a vertical transect line from one semi-exposed rocky headland (Cattle Point, San Juan Island). These subpopulations differed in their $\mathrm{pH}$ compensation points and residual DIC, with the pattern again following the general multi-species pattern (Fig. 
2 and 4$)$. The highest specimens $(+1.4 \mathrm{~m})$ were not able to raise the $\mathrm{pH}$ or to deplete the DIC (Fig. 5) to the same extent as conspecific specimens collected from lower in the intertidal (one-way ANOVA, Tukey HSD, $\mathrm{F}=10.35$, df $=3, p<0.01$ ). 


\section{DISCUSSION}

The $\mathrm{pH}$ compensation points reached at the end of the drift trials and the estimated residual DIC remaining in the medium generally defined a gradient in relation to the tidal height from which the algae were collected. Previous reports have suggested that an increase in DIC removal efficiency is correlated with increasing tidal height: subtidal species being strict or close to strict $\mathrm{CO}_{2}$ users while intertidal species are able to use $\mathrm{HCO}_{3}{ }^{-}$with varying degrees of efficiency (Maberly 1990, Johnston et al. 1992 , Larsson et al. 1997, Flores-Moya and Fernández 1998, Mercado et al. 1998, Choo et al. 2002, Snoeijs et al. 2002).

This pattern was in general supported by the data collected in this new investigation, but some noteworthy departures from the pattern were found. The subtidal and lower intertidal red algae in this study relied heavily on dissolved $\mathrm{CO}_{2}$, while many upper intertidal red algae were highly effective in $\mathrm{HCO}_{3}{ }^{-}$utilization. Three clusters of upper intertidal species or populations with different DIC scavenging abilities were identified, suggesting: 1) that tidal height or exposure gradients alone do not adequately predict the carbon utilization strategies of intertidal seaweeds, and 2) that DIC scavenging efficiency describes a modal rather than a monotonically increasing relationship with tidal height, at least among intertidal red algal seaweeds.

The first cluster of upper intertidal red algae contained all species other than Porphyra spp. collected in the eulittoral zone $(+0.5$ to $+1.3 \mathrm{~m})$. DIC scavenging by species in this cluster was very effective and generally increased with tidal height. The high DIC scavenging ability could allow these species to take advantage of the high 
irradiance they experience, especially during periods of optimal hydration (Dring and Brown 1982, Beer and Eshel 1983, Surif and Raven 1989 and 1990, Giordano and Maberly 1989, Beer and Israel 1990, Madsen and Maberly 1990, Bell 1993, Mercado et al. 1998, Mercado and Niell 1999 and 2000). These species also produced a reduction of alkalinity during the drift trials.

During the course of $\mathrm{pH}$ drift experiments, the removal of DIC is assumed to occur at constant alkalinity (Allen and Spence 1981, Stumm and Morgan 1981, Maberly and Spence 1983, Axelsson 1988, Prins and Elzenga 1989). The assumption of constant alkalinity is based upon the fact that each carbon molecule removed from the medium is eventually replaced in a nearly stoichiometric manner by a molecule of base $\left(\mathrm{OH}^{-}\right)$, and since there is no change in the ratio of bases and protons in the surrounding medium, the alkalinity remains constant (Uusitalo 1996). This assumption held true for the majority but not all of the experimental $\mathrm{pH}$ drift trials. In trials where the final $\mathrm{pH}$ reached very high values, above 9.6 as estimated by Piecewise Regression Analysis (Loss function: least squares, variance explained $70.4 \%$ ), a reduction of alkalinity from the initial values was detected. This alkalinity reduction in the medium was consistent with the decline of DIC found at elevated $\mathrm{pH}$ values, and it has been reported by other authors (Johnston and Raven 1986, Axelsson and Uusitalo 1988, Maberly 1990, Menéndez et al. 2001, Choo et al. 2002). Decreased alkalinities at the end of the $\mathrm{pH}$ drift experiment were notable only for the specimens collected from the upper intertidal zone and for Neorhodomela oregona from high pools. As pointed out by Maberly (1990), this problem does not invalidate the $\mathrm{pH}$-drift technique; rather it highlights discrete physiological differences in DIC depletion abilities among the macroalgae under investigation. The observed decrease in alkalinity 
could either indicate a direct net uptake of the chemical species contributing to the total alkalinity, such as $\mathrm{HCO}_{3}{ }^{-}$(Menéndez et al. 2001, Choo et al. 2002), or could be caused by an excess of $\mathrm{OH}^{-}$and the resulting precipitation of $\mathrm{CaCO}_{3}$ (Maberly 1990, Menéndez et al. 2001) or $\mathrm{Mg}(\mathrm{OH})_{2}$ (Axelsson and Uusitalo 1988).

The second upper intertidal species cluster consisted of taxa or populations that appeared far less effective in DIC scavenging. These species are seasonal or year-round inhabitants of the extreme upper edge of the eulittoral zone. Their reduced $\mathrm{pH}$ compensation points and higher residual DIC concentrations were comparable to red algae from the subtidal-intertidal boundary zone rather than the eulittoral zone. The general pattern observed in this study is, therefore, that efficiency of DIC utilization tended to increase with tidal height, but only up to a "threshold" height, above which the inorganic carbon acquisition efficiency sharply decreased.

From tide charts, the algae included in the littoral fringe were estimated to have spent on average $42 \%$ of their daytime hours exposed to air in the two months previous to their collection. The frequent exposure to air could have allowed the algae to take advantage of the atmospheric $\mathrm{CO}_{2}$ rapidly dissolving into the ephemeral and thin airwater interface covering the thallus until desiccation sufficiently reduced the thallus water content and photosynthetic processes stopped. The presence and operation of a mechanism for direct $\mathrm{HCO}_{3}{ }^{-}$uptake might be energetically disadvantageous in such a habitat. As a consequence, we would expect to find high extCA activity within this group, given the facilitating effect this enzyme could have on the $\mathrm{CO}_{2}$ supply from the air to the thallus as suggested by other work (Surif and Raven 1989 and 1990, Giordano and 
Maberly 1989, Beer and Israel 1990, Mercado et al. 1998, Mercado and Niell 1999 and 2000). Unfortunately, we made no attempt to identify or isolate such an extCA.

The third upper intertidal cluster included the four Porphyra species tested in this study. The ability of Porphyra to deplete DIC in the medium was less than for other species collected at comparable tidal height. This could be the result of physiological 'limitations' specific to the genus Porphyra and, if so, would represent the only evidence of a taxon-based effect on DIC uptake found in this study. When Porphyra species were analyzed separately, their residual DIC did decrease significantly with the species' intertidal height, but a dramatic change between eulittoral and littoral fringe species was not apparent. Porphyra torta, the highest Porphyra species in the intertidal, was a significantly less effective DIC scavenger than Porphyra perforata (one-way ANOVA and post-hoc test on residual $\mathrm{DIC} ; \mathrm{F}=5.5, \mathrm{df}=3, p<0.05)$.

No other taxon-based effect was evident among the 38 species investigated, although it is possible that these results were due to the lack of enough replication within each taxonomic entity utilized in the statistical analyses - family and order level.

Mastocarpus papillatus was collected at four different heights along a rocky-coast transect line. All collections were grouped within the upper intertidal habitat zone as defined here. The specimens collected from the highest intertidal location reached $\mathrm{pH}$ compensation points and residual DIC values that were significantly different from specimens collected lower in the intertidal. Thus the general pattern found among intertidal red algal species was also found among populations of this one species which has a broad vertical distribution on west coast rocky shorelines. One explanation would be that Mastocarpus is able to acclimate to certain environmental conditions by changing 
the extent of direct bicarbonate utilization depending upon whether the energetic expense is counterbalanced by overcoming carbon limitation. The ability to use bicarbonate as a source of inorganic carbon can vary within the same species throughout the growing season (Menéndez et al. 2001) and with the age of the organism (Prins and Elzenga 1989). The fact that carbon concentrating mechanisms can be induced under certain environmental conditions as a function of relative availability of $\mathrm{HCO}_{3}{ }^{-}$versus $\mathrm{CO}_{2}$ has been previously reported (Sand-Jensen and Gordon 1984, Surif and Raven 1990, Kübler and Raven 1994, Larsson and Axelsson 1999, Andría et al. 2001). Acclimation for carbon acquisition mechanisms was also found in Enteromorpha intestinalis (Larsson et al. 1997) and in Ulva lactuca where the authors were able to "train" the algae to express specific carbon uptake mechanisms (Axelsson et al. 1995 and 1999). Another possible explanation for the pattern exhibited by Mastocarpus would be the differential survivorship of specific genotypes able to express carbon acquisition strategies particularly suited for the environmental conditions experienced in the four collection sites. In this study we made no attempt to further investigate either the occurrence of acclimation or the differential survivorship of specific genotypes in Mastocarpus.

Neorhodomela oregona was found in a series of very high tidal pools where there is seldom (probably only during storms) any degree of water exchange during the summer season. This series of pools were occupied exclusively by $N$. oregona in dense populations. Under conditions of high irradiance, very low water exchange and high population densities, it is likely that this species experiences drastic and prolonged depletions of DIC, and thus a great deal of carbon limitation. In these high tidal pools the main source of inorganic carbon would either be from the occasional wave action 
(unusual for the sampling sites during the summer months), or from diffusion through the air-water interface. The degree of inorganic carbon diffusion from the air would be a function of surface to volume ratios of each tidal pool, and of the $\mathrm{pH}$ values attained in the water by the prolonged DIC acquisition by $N$. oregona. Higher $\mathrm{pH}$ values would increase the rate of $\mathrm{CO}_{2}$ diffusion into the water, where it would readily hydrate and dissociate to form bicarbonate. The ability to actively and directly take up the $\mathrm{HCO}_{3}{ }^{-}$ fraction of the DIC would certainly be of significant ecological advantage, and it may, at least partly, explain the overwhelming dominance of this species in such a harsh habitat. 


\section{CONCLUSIONS}

The major objective of this study was to evaluate the extent to which red macroalgae were able to deplete the DIC from the seawater and to utilize the $\mathrm{HCO}_{3}^{-}$ fraction of the DIC. There was no evidence that members of different families or orders of red algae differed in the ability to utilize the bicarbonate fraction of DIC, but habitat measured as tidal height or depth, was certainly a major factor associated with the degree of DIC depletion from the medium. The results substantiate previously reported patterns of inorganic carbon acquisition related to tidal height, but also clearly demonstrate that the model of a monotonic relationship between tidal height and DIC scavenging ability is too simplistic. The data suggest that DIC scavenging adaptations are of critical importance in defining seaweed zonation patterns on rocky shorelines and that these physiological pathways are likely to be under active evolutionary selection pressure. Worthy of consideration for possible future investigations are 1) defining seasonal patterns in the ability to deplete DIC in wild populations, and 2) the occurrence and extent of acclimation with regards to carbon utilization within the same species and among congeneric species as a response to habitat as exemplified here by Mastocarpus papillatus and Porphyra spp. 
Figure 1. $\mathrm{pH}$ Compensation Point reached after the drift is plotted against the residual DIC. The solid line represents the expected DIC concentration predicted from a given $\mathrm{pH}$ assuming constant alkalinity. The distribution of the residual DIC data shows deviations from the theoretical relationship between $\mathrm{pH}$ and DIC. The residual DIC estimated after the drift was significantly different from the calculated expected DIC (t-test, $p<0.0001$, df =117). A special note for the rhodophytes that reached higher $\mathrm{pH}$ compensation points; for these species the measured residual DIC tended to be consistently lower than the value predicted on the basis of their final $\mathrm{pH}$.

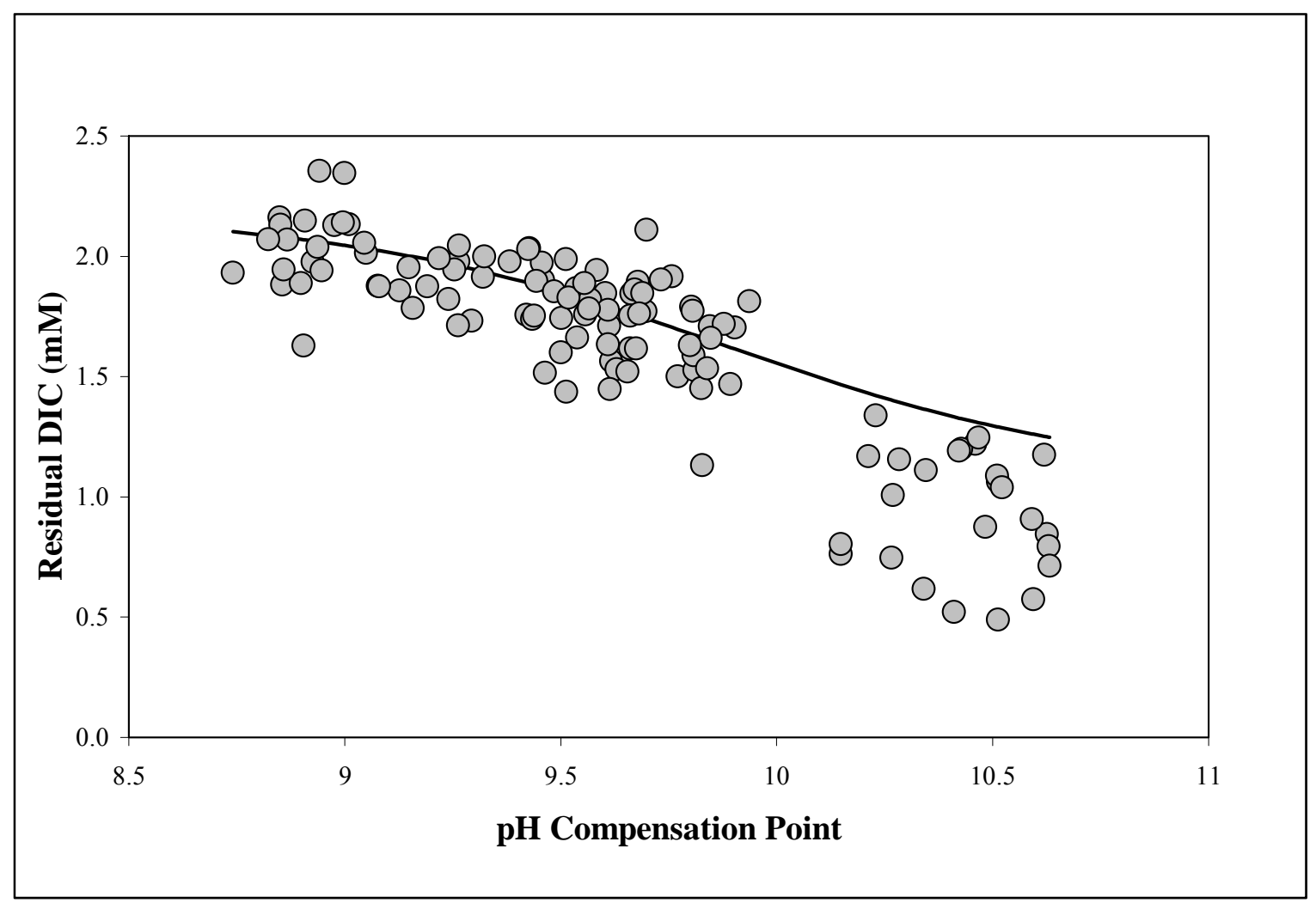


Figure 2. The species average $\mathrm{pH}$ Compensation Point is plotted against the residual DIC measured after the drift. The solid line represents the expected DIC concentration predicted from a given $\mathrm{pH}$ assuming constant alkalinity. The species were divided into discrete habitat categories following the results of classification tree analysis (Proportional Reduction in Error, PRE $=0.78$ ). Subtidal species were characterized by low $\mathrm{pH}$ compensation point and high residual DIC. Lower intertidal species demonstrated a higher degree of DIC depletion from the medium. The high pool Neorhodomela oregona was among the most effective DIC scavengers. The upper intertidal macroalgae showed a discontinuity in the pattern otherwise found for the other species in this study.

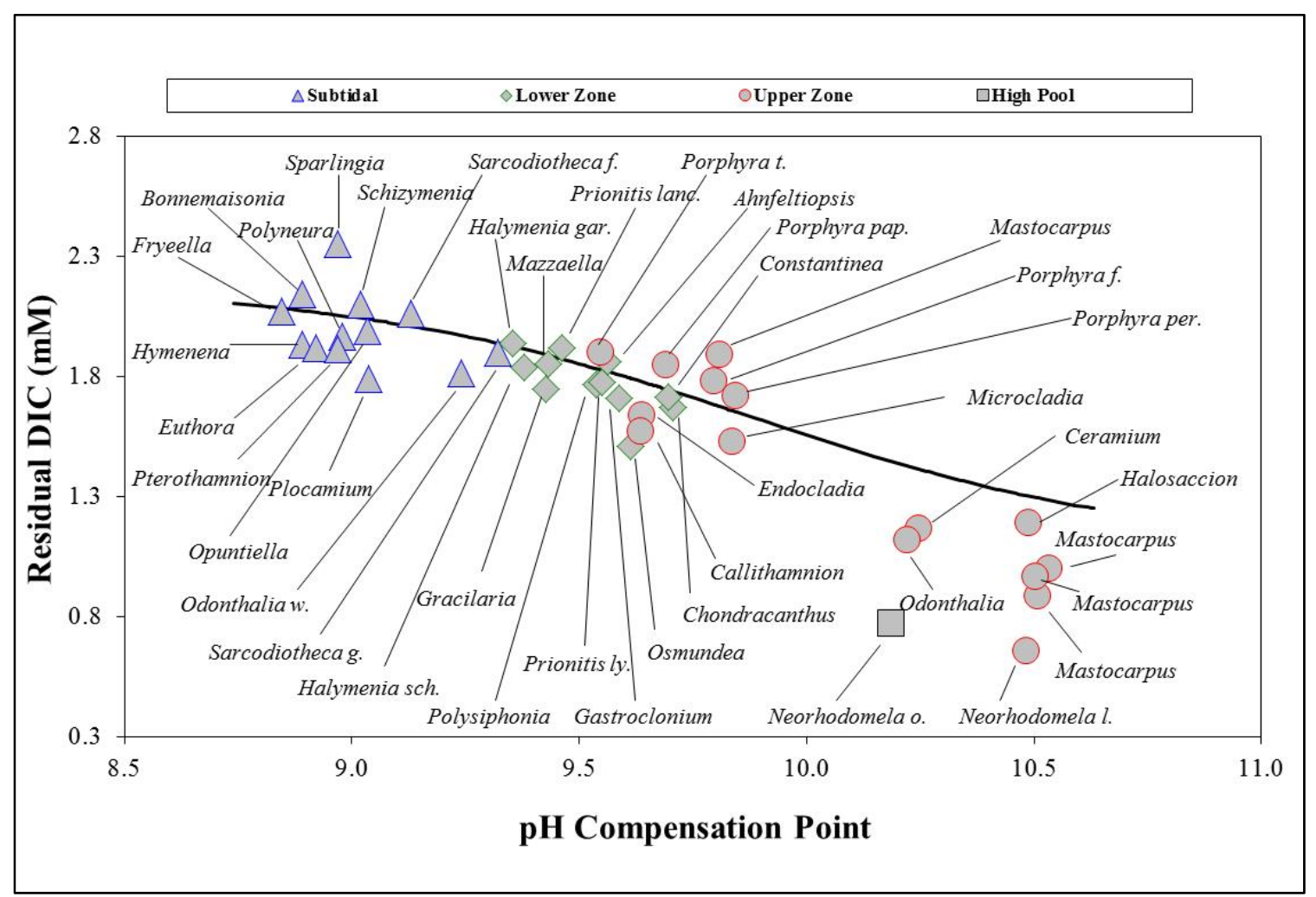


Figure 3. The respective average $\mathrm{pH}$ Compensation Point reached plotted against the residual DIC measured after the drift for the 4 species of Porphyra (in red are the new taxonomic names for each species - see text for explanations). The symbols are mean values for each tidal height. The four different species of Porphyra were collected at different tidal heights within the same area; ANOVA and Tukey Post-hoc test showed a significant difference between the upper specimens $P$. torta and the lower P. perforata $(\mathrm{p}<0.01)$

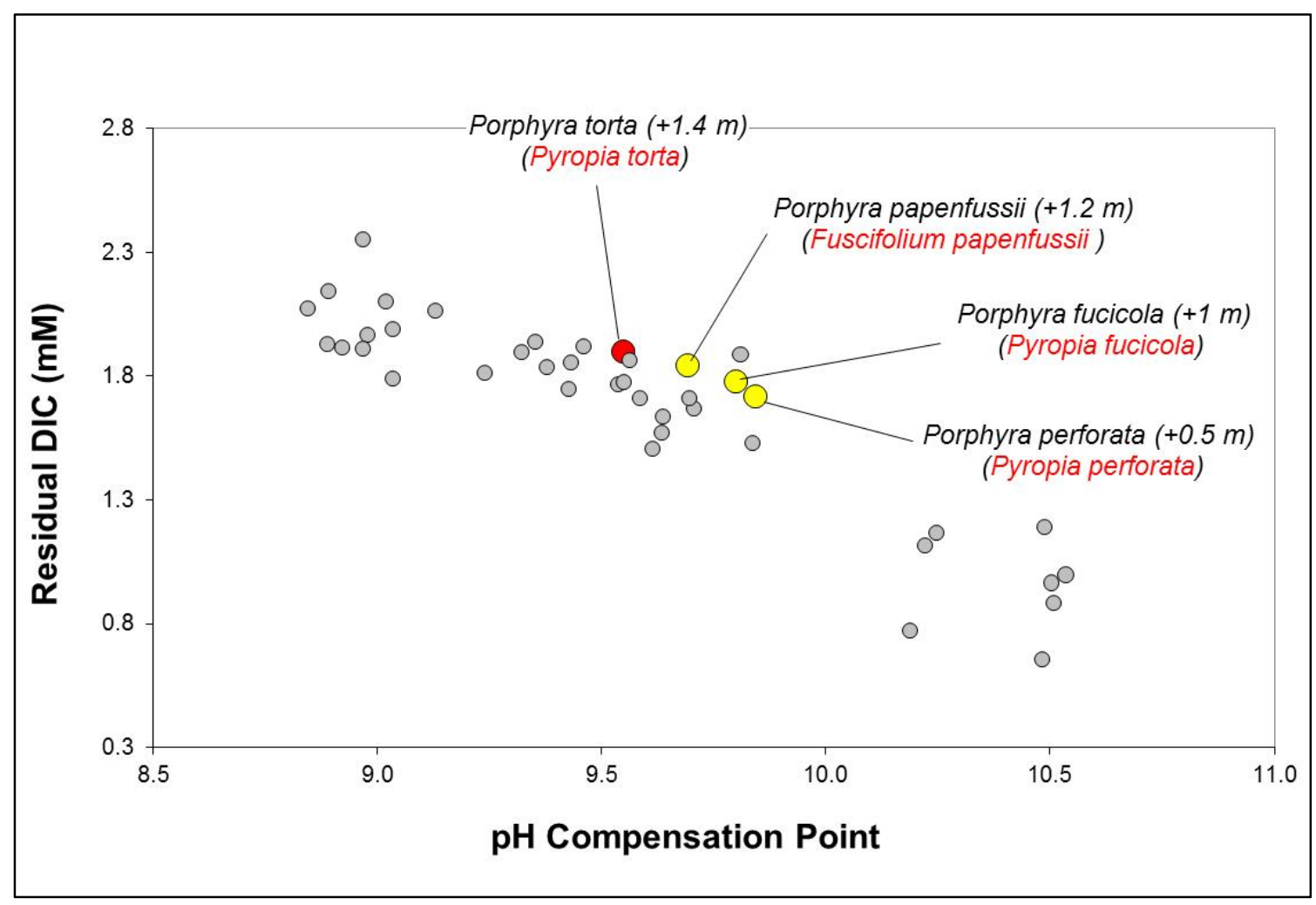


Figure 4. The respective average $\mathrm{pH}$ Compensation Point reached plotted against the residual DIC measured after the drift for Mastocarpus papillatus. The symbols are mean values for each tidal height. M. papillatus was collected along a vertical transect and the specimens collected from the highest location were significantly different then the lower specimens with regards to both $\mathrm{pH}$ compensation point and residual $\mathrm{DIC}(\mathrm{p}<0.01$, ANOVA and Tukey HSD post-hoc test).

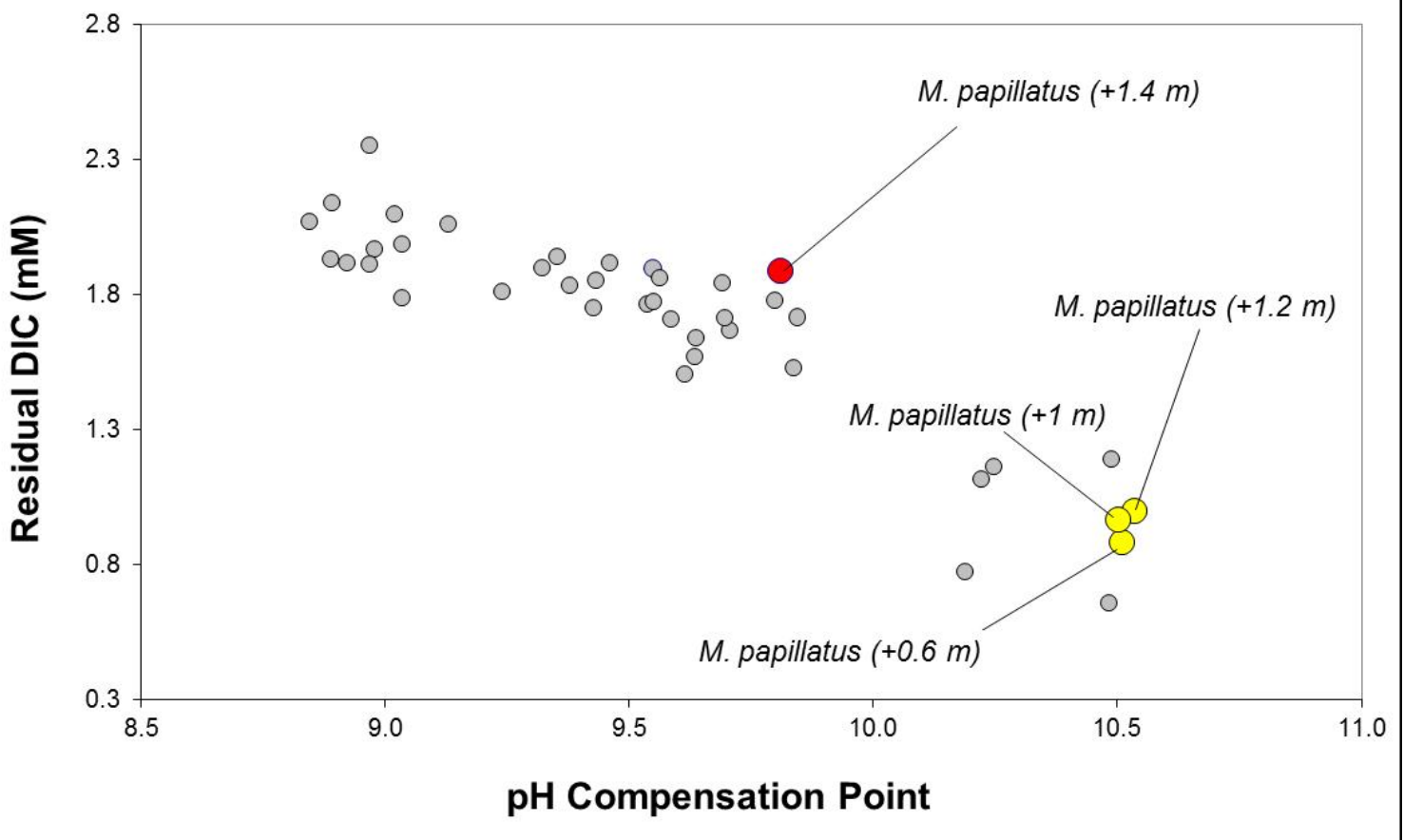


Table 1. Nomenclature: Alphabetical List of Species Included in This Study

Species nomenclature accordingly to Gabrielson et al. (2000). Taxonomic names revised after the publication of the present work are noted.

Ahnfeltiopsis leptophylla (J. Agardh) P. Silva et DeCew

Bonnemaisonia nootkana (Esper) P. Silva

Callithamnion pikeanum Harvey

Ceramium pacificum (Collins) Kylin

Chondracanthus exasperatus (Harvey et Bailey) Hughey

Constantinea subulifera Setchell

Endocladia muricata (Postel et Ruprecht) J. Agardh

Euthora cristata (C. Agardh) J. Agardh

Fryeella gardneri (Setchell) Kylin

Gastroclonium subarticulatum (Turner) Kützing

Gracilaria pacifica Abbott

Halosaccion glandiforme (Gmelin) Ruprecht

Halymenia gardneri (Kylin) Parkinson

Halymenia schizymenioides Hollenberg et Abbott

Hymenena flabelligera (J. Agardh) Kylin

Mastocarpus papillatus (C. Agardh) Kützing

Mazzaella splendens (Setchell et Gardner) Fredericq

Microcladia borealis Ruprecht 
Neorhodomela larix (Turner) Masuda

Neorhodomela oregona (Doty) Masuda

Odonthalia floccosa (Esper) Falkenberg

Odonthalia washingtoniensis Kylin

Opuntiella californica (Farlow) Kylin

Osmundea spectabilis (Postels et Ruprecht) Nam

Plocamium cartilagineum (Linnaeus) P. S. Dixon

Polyneura latissima (Harvey) Kylin

Polysiphonia hendryi gardneri (Kylin) Hollenberg

Porphyra fucicola V. Krishnamurthy (now Pyropia fucicola (V.Krishnamurthy)

S.C.Lindstrom).

Porphyra papenfussii V. Krishnamurthy (syn. Fuscifolium papenfussii

(V.Krishnamurthy) S.C.Lindstrom)

Porphyra perforata J. Agardh (now Pyropia perforata (J.Agardh) S.C.Lindstrom)

Porphyra torta V. Krishnamurthy (now Pyropia torta (V.Krishnamurthy) S.C.Lindstrom)

Prionitis lanceolata (Harvey) Harvey

Prionitis lyallii Harvey

Pterothamnion pectinatum (Kylin) Athanasiadis et Kraft

Sarcodiotheca furcata (Setchell et Gardner) Kylin

Sarcodiotheca gaudichaudii (Montagne) Gabrielson

Schizymenia pacifica (Kylin) Kylin

Sparlingia pertusa (Postels et Ruprecht) Saunders, Strachan et Kraft 
Table 2. The $\mathrm{pH}$ compensation point and residual DIC measured at the end of $\mathrm{pH}$ drift experiments; species are ranked by the tidal height or depth (in meters) at which they were collected. Numbers provided in the table are mean values and standard deviations (in parenthesis). Habitat categories were identified by the Regression Tree algorithm, Least Square Loss.

\begin{tabular}{|c|c|c|c|c|c|}
\hline Species & $\mathbf{N}$ & $\begin{array}{c}\text { Tidal } \\
\text { Height }\end{array}$ & $\begin{array}{l}\text { Habitat } \\
\text { Category }\end{array}$ & $\begin{array}{c}\text { pH } \\
\text { Compensation } \\
\text { Point }\end{array}$ & $\begin{array}{c}\text { Residual } \\
\text { DIC } \\
\left(\mathrm{mmol} \cdot \mathrm{L}^{-1}\right)\end{array}$ \\
\hline Neorhodomela oregona & 3 & 2.5 & "High Pool & $10.19(0.068)$ & $0.77(0.029)$ \\
\hline Callithamnion pikeanum & 3 & 1.5 & Upper Zone & $9.64(0.158)$ & $1.64(0.223)$ \\
\hline Endocladia muricata & 3 & 1.5 & Upper Zone & $9.64(0.023)$ & $1.57(0.043)$ \\
\hline Mastocarpus papillatus & 4 & 1.4 & Upper Zone & $9.81(0.104)$ & $1.89(0.171)$ \\
\hline Porphyra torta & 3 & 1.4 & Upper Zone & $9.55(0.078)$ & $1.88(0.048)$ \\
\hline Mastocarpus papillatus & 3 & 1.3 & Upper Zone & $10.51(0.207)$ & $0.88(0.111)$ \\
\hline Mastocarpus papillatus & 3 & 1.2 & Upper Zone & $10.54(0.088)$ & $1.00(0.260)$ \\
\hline Porphyra papenfussii & 4 & 1.2 & Upper Zone & $9.69(0.031)$ & $1.85(0.055)$ \\
\hline Ceramium pacificum & 2 & 1 & Upper Zone & $10.25(0.051)$ & $1.16(0.010)$ \\
\hline Halosaccion glandiforme & 3 & 1 & Upper Zone & $10.49(0.112)$ & $1.19(0.013)$ \\
\hline Mastocarpus papillatus & 4 & 1 & Upper Zone & $10.50(0.024)$ & $0.97(0.330)$ \\
\hline Porphyra fucicola & 3 & 1 & Upper Zone & $9.80(0.107)$ & $1.78(0.072)$ \\
\hline Neorhodomela larix & 4 & 0.6 & Upper Zone & $10.48(0.129)$ & $0.66(0.173)$ \\
\hline Odonthalia floccosa & 4 & 0.6 & Upper Zone & $10.22(0.282)$ & $1.11(0.189)$ \\
\hline Microcladia borealis & 3 & 0.5 & Upper Zone & $9.84(0.049)$ & $1.53(0.061)$ \\
\hline Porphyra perforata & 3 & 0.5 & Upper Zone & $9.84(0.036)$ & $1.72(0.056)$ \\
\hline Polysiphonia hendryi gardneri & 2 & 0.25 & Lower Zone & $9.54(0.001)$ & $1.76(0.145)$ \\
\hline Prionitis lanceolata & 3 & 0 & Lower Zone & $9.46(0.037)$ & $1.92(0.153)$ \\
\hline Prionitis lyallii & 4 & 0 & Lower Zone & $9.55(0.107)$ & $1.77(0.183)$ \\
\hline Ahnfeltiopsis leptophyllus & 3 & -0.25 & Lower Zone & $9.56(0.049)$ & $1.86(0.111)$ \\
\hline
\end{tabular}




\begin{tabular}{|c|c|c|c|c|c|}
\hline Halymenia gardneri & 2 & -0.3 & Lower Zone & $9.35(0.128)$ & $1.94(0.058)$ \\
\hline Mazzaella splendens & 3 & -0.3 & Lower Zone & $9.43(0.158)$ & $1.85(0.093)$ \\
\hline Chondracanthus exasperatus & 4 & -0.4 & Lower Zone & $9.71(0.140)$ & $1.67(0.166)$ \\
\hline Gastroclonium subarticulatum & 2 & -0.4 & Lower Zone & $9.59(0.032)$ & $1.71(0.105)$ \\
\hline Constantinea subulifera & 2 & -0.5 & Lower Zone & $9.70(0.201)$ & $1.71(0.251)$ \\
\hline Gracilaria pacifica & 2 & -0.5 & Lower Zone & $9.43(0.009)$ & $1.75(0.012)$ \\
\hline Halymenia schizymenioides & 2 & -0.5 & Lower Zone & $9.38(0.084)$ & $1.83(0.115)$ \\
\hline Osmundea spectabilis & 4 & -0.5 & Lower Zone & $9.61(0.072)$ & $1.51(0.083)$ \\
\hline Hymenena flabelligera & 2 & -1 & Subtidal & $8.89(0.050)$ & $1.93(0.067)$ \\
\hline Plocamium cartilagineum & 3 & -1 & Subtidal & $9.04(0.116)$ & $1.79(0.138)$ \\
\hline Bonnemaisonia nootkana & 3 & -5 & Subtidal & $8.89(0.073)$ & $2.14(0.018)$ \\
\hline Euthora cristata & 2 & -5 & Subtidal & $8.92(0.035)$ & $1.91(0.037)$ \\
\hline Fryeella gardneri & 2 & -5 & Subtidal & $8.85(0.031)$ & $2.07(0.001)$ \\
\hline Odonthalia washingtoniensis & 3 & -5 & Subtidal & $9.24(0.052)$ & $1.81(0.072)$ \\
\hline Opuntiella californica & 3 & -5 & Subtidal & $9.04(0.113)$ & $1.99(0.181)$ \\
\hline Polyneura latissima & 3 & -5 & Subtidal & $8.98(0.212)$ & $1.97(0.043)$ \\
\hline Pterothamnion pectinatum & 2 & -5 & Subtidal & $8.97(0.156)$ & $1.91(0.049)$ \\
\hline Sarcodiotheca furcata & 3 & -20 & Subtidal & $9.13(0.194)$ & $2.06(0.080)$ \\
\hline Sarcodiotheca gaudichaudii & 3 & -20 & Subtidal & $9.32(0.060)$ & $1.90(0.160)$ \\
\hline Schizymenia pacifica & 2 & -20 & Subtidal & $9.02(0.035)$ & $2.10(0.060)$ \\
\hline Sparlingia pertusa & 2 & -20 & Subtidal & $8.97(0.041)$ & $2.35(0.007)$ \\
\hline
\end{tabular}




\section{BIBLIOGRAPHY}

Abbott, I. A. \& Hollenberg, G. J. 1976. Marine Algae of California. Stanford University Press, Stanford, CA, 827 pp.

Allen, E. D. \& Spence, D. H. N. 1981. The differential ability of aquatic plants to utilize the inorganic carbon supply in fresh waters. New Phytol., 87:269-83.

Andría, J. R., Pérez-Lloréns, J. L. \& Vergara, J. J. 1999. Mechanisms of inorganic carbon acquisition in Gracilaria gaditana nom. prov. (Rhodophyta). Planta, 208:564-73.

Andría, J. R., Brun, F. G., Pérez-Lloréns, J. L. \& Vergara, J. J. 2001. Acclimation responses of Gracilaria sp. (Rhodophyta) and Enteromorpha intestinalis (Chlorophyta) to changes in the external inorganic carbon concentration. Botanica Marina, 44:361-70.

Axelsson, L. 1988. Changes in $\mathrm{pH}$ as measure of photosynthesis by marine macroalgae. Marine Biology, 97:287-94.

Axelsson, L. \& Uusitalo, J. 1988. Carbon acquisition strategies for marine macroalgae. Marine Biology, 97:295-300.

Axelsson, L., Ryberg, H. \& Beer, S. 1995. Two modes of bicarbonate utilization in the marine green macroalga Ulva lactuca. Plant, Cell and Environment, 18:439-45.

Axelsson, L., Larsson, C. \& Ryberg, H. 1999. Affinity, capacity and oxygen sensitivity of two different mechanisms for bicarbonate utilization in Ulva lactuca L. (Chlorophyta). Plant, Cell and Environment, 22:969-78.

Axelsson, L., Mercado, J. M. \& Figueroa, F. L. 2000. Utilization of $\mathrm{HCO}_{3}{ }^{-}$at high $\mathrm{pH}$ by the brown macroalga Laminaria saccharina. European Journal of Phycology, 35:53-9.

Badger, M. R. \& Price, G. D. 1994. The role of carbonic anhydrase in photosynthesis. Annu. Rev. Plant Mol. Biol., 45:369-92. 
Beer, S. 1994. Mechanisms of inorganic carbon acquisition in marine macroalgae (with special reference to the Chlorophyta). Progress in Phycological Research, 10:179-207.

Beer, S. \& Eshel, A. 1983. Photosynthesis of Ulva sp. I. Effects of desiccation when exposed to air. J. Exp. Mar. Biol. Ecol., 70:91-7.

Beer, S. \& Israel, A. 1990. Photosynthesis of Ulva fasciata IV.pH, carbonic anhydrase, and inorganic carbon conversions in the unstirred layer. Plant, Cell and Environment, 13:555-60.

Bell, E. C. 1993. Photosynthetic response to temperature and desiccation of the intertidal alga Mastocarpus papillatus. Marine Biology, 117:337-46.

Choo, K., Snoeijs, P. \& Pedersén, M. 2002. Uptake of inorganic carbon by Cladophora glomerata (Chlorophyta) from the Baltic Sea. J. Phycol., 38:493-502.

Cook, C. M., Lanaras, T. \& Colman, B. 1986. Evidence for bicarbonate transport in species of red and brown macrophytic marine algae. Journal of Experimental Botany, 37(180):977-84.

Cook, C. M., Lanaras, T. \& Roubelakis-Angelakis, K. A. 1988. Bicarbonate transport and alkalization of the medium by four species of Rhodophyta. Journal of Experimental Botany, 39(206):1185-98.

Dring, M. J. \& Brown, F. A. 1982. Photosynthesis of intertidal brown algae during and after periods of emersion: a renewed search for physiological causes of zonation. Mar. Ecol. Prog. Ser., 8:301-8.

Flores-Moya, A. \& Fernández, J. A. 1998. The role of external carbonic anhydrase in the photosynthetic use of inorganic carbon in the deep water alga Phyllariopsis purpurascens (Laminariales, Phaeophyta). Planta, 207:115-9.

Gabrielson, P. W., Widdowson, T. B., Lindstrom, S. C., Hawkes, M. W. \& Scagel, R. F. 2000. Keys to the Benthic Marine Algae and Seagrasses of British Columbia, Southeast Alaska, Washington and Oregon. Phycological Contribution Number 5. Dept. of Botany, University of British Columbia, Vancouver, BC, 190 pp. 
Giordano, M., \& Maberly, S. C. 1989. Distribution of carbonic anhydrase in British marine macroalgae. Oecologia, 81:534-9.

Granbom, M. \& Pedersén, M. 1999. Carbon acquisition strategies of the red alga Euchema denticulatum. Hydrobiologia, 398/399:349-54.

Haglund, K., Ramazanov, Z., Mtolera, M. \& Pedersén, M. 1992. Role of external carbonic anhydrase in light dependent alkalization by Fucus serratus L. and Laminaria saccharina (L.) Lamour. (Phaeophyta). Planta, 188:1-6.

Hofslagare, O., Samuelsson, G., Hällgren, J. -E., Pejryd, C. \& Sjöberg, S. 1985. A comparison between three methods of measuring photosynthetic uptake of inorganic carbon in algae. Photosynthetica, 19(4):578-85.

Israel, A. \& Beer, S. 1992. Photosynthetic carbon acquisition in the red alga Gracilaria conferta II. Rubisco carboxylase kinetics, carbonic anhydrase and $\mathrm{HCO}_{3}{ }^{-}$uptake. Marine Biology, 112:697-700.

Johnston, A. M. 1991. The acquisition of inorganic carbon by marine macroalgae. Canadian Journal of Botany, 69:1123-32.

Johnston, A. M. \& Raven, J. A. 1986. The utilization of bicarbonate ions by the macroalga Ascophyllum nodosum (L.) Le Jolis. Plant Cell Environment, 9:175-84.

Johnston, A. M., Maberly, S. C. \& Raven, J. A. 1992. The acquisition of inorganic carbon by four red macroalgae. Oecologia, 92:317-26.

Joliffe, E. A. \& Tregunna, E. B. 1970. Studies on $\mathrm{HCO}_{3}{ }^{-}$ion uptake during photosynthesis in benthic marine algae. Phycologia, 9(3/4):293-303.

Kerby, N. W. \& Raven, J. A. 1985. Transport and fixation of inorganic carbon by marine algae. Adv. Bot. Res., 11:71-123.

Kübler, J. E. \& Raven, J. A. 1994. Consequences of light limitation for carbon acquisition in three rhodophytes. Marine Ecology Progress Series, 110:203-9. 
Larsson, C. \& Axelsson, L. 1999. Bicarbonate uptake utilization in marine macroalgae. Eur. J. Phycol., 34:79-86.

Larsson, C., Axelsson, L., Ryberg, H. \& Beer, S. 1997. Photosynthetic carbon utilization by Enteromorpha intestinalis (Chlorophyta) from a Swedish rockpool. Eur. J. Phycol., 32:49-54.

Lobban, C. S. \& Harrison, P. J. 1997. Seaweed Ecology and Physiology. Cambridge University Press, New York, NY, 366 pp.

Lucas, W. J. 1983. Photosynthetic assimilation of exogenous $\mathrm{HCO}_{3}{ }^{-}$by aquatic plants. Ann. Rev. Plant Physiol., 34:71-104.

Maberly, S. C. 1990. Exogenous sources of inorganic carbon for photosynthesis by marine macroalgae. J. Phycol., 26:439-49.

Maberly, S. C. \& Madsen, T. V. 2002. Use of bicarbonate ions as source of carbon in photosynthesis by Callitriche hermaphroditica. Aquatic Botany, 73:1-7.

Maberly, S. C. \& Spence, D. H. N. 1983. Photosynthetic inorganic carbon use by freshwater plants. Journal of Ecology, 71:705-24.

Madsen, T. V. \& Maberly, S. C. 1990. A comparison of air and water as environments for photosynthesis by the intertidal alga Fucus spiralis (Phaeophyta). J. Phycol., 26:2430 .

Menéndez, M., Martínez, M. \& Comín, F. A. 2001. A comparative study of the effect of $\mathrm{pH}$ and inorganic carbon resources on the photosynthesis of three floating macroalgae species of a Mediterranean coastal lagoon. Journal of Experimental Marine Biology and Ecology, 256:123-36.

Mercado, J. M. \& Niell, F. X. 1999. Carbonic anhydrase activity and use of $\mathrm{HCO}_{3}{ }^{-}$in Bostrychia scorpioides (Ceramiales, Rhodophyceae). European Journal of Phycology, 34:13-9. 
Mercado, J. M. \& Niell, F. X. 2000. Carbon dioxide uptake by Bostrychia scorpioides (Rhodophyceae) under emersed conditions. European Journal of Phycology, 35: 45-51.

Mercado, J. M., Gordillo, F. J. L., Figueroa, F. L. \& Niell, F. X. 1998. External carbonic anhydrase and affinity for inorganic carbon in intertidal macroalgae. Journal of Experimental Marine Biology and Ecology, 221:209-20.

Price, G. D. \& Badger, M. R. 1985. Inhibition by proton buffers of photosynthetic utilization of bicarbonate in Chara corallina. Aust. J. Plant Physiol., 12:257-67.

Prins, H. B. A. \& Elzenga, J. T. M. 1989. Bicarbonate utilization: function and mechanisms. Aquat. Bot., 34:59-83.

Raven, J. A. 1997. Putting the C in phycology. Eur. J. Phycol., 32:319-33.

Raven, J.A. \& Lucas, W. J. 1985. The energetics of carbon acquisition. In Lucas, W.J. \& Berry, J.A. [Eds.] Inorganic Carbon Uptake by Aquatic Photosynthetic Organisms. American Society of Plant Physiologists, Rockville, MD, pp. 305-24.

Sand-Jensen, K. \& Gordon, D. M. 1984. Differential ability of marine and freshwater macrophytes to utilize $\mathrm{HCO}_{3}{ }^{-}$and $\mathrm{CO}_{2}$. Marine Biology, 80:247-53.

Snoeijs, P., Klenell, M., Choo, K. S., Comhaire, I., Ray, S. \& Pedersén, M. 2002. Strategies for carbon acquisition in the red marine macroalga Coccotylus truncatus from the Baltic Sea. Marine Biology, 140:435-44.

StatSoft, Inc. 2001. STATISTICA for Windows [Computer program manual]. Tulsa, OK: StatSoft, Inc., 2300 East 14th Street, Tulsa, OK 74104, email: info@statsoft.com, WEB: http://www.statsoft.com

Stumm, W. \& Morgan, J. J. 1981. Aquatic Chemistry. An Introduction Emphasizing Chemical Equilibria in Natural Waters. J. Wiley and Sons, Ed. Wiley-Interscience Publication, New York, NY, 780 pp.

Surif, M. B. \& Raven, J. A. 1989. Exogenous inorganic carbon sources for photosynthesis in seawater by members of the Fucales and the Laminariales (Phaeophyta): ecological and taxonomic implications. Oecologia, 78:97-105. 
Surif, M. B. \& Raven, J. A. 1990. Photosynthetic gas exchange under emersed conditions in eulittoral and normally submersed members of the Fucales and the Laminariales: interpretation in relation to $\mathrm{C}$ isotope ratio and $\mathrm{N}$ and water use efficiency. Oecologia, 82:68-80.

SYSTAT Version 10.2. 2002. SYSTAT Software Inc. Web: http://www.systat.com

Uusitalo, J. 1996. Algal carbon uptake and the difference between alkalinity and high $\mathrm{pH}$ (“alkalization") exemplified with a pH drift experiment. Sci. Mar., 60(suppl.):29-134. 


\section{FINAL CONCLUSIONS AND SECOND THOUGHTS}

Since the publication of this work, the inorganic carbon acquisition in aquatic photosynthetic organisms has continued to receive a great deal of attention. Some of the related works published have been review articles on algal inorganic carbon acquisition (notable example, Giordano et al. 2005). Most of the advances in the inorganic carbon acquisition in aquatic photosynthetic organisms lead to a more intimate understanding of the mechanisms, of the genetic aspects of their expression, and of the 'triggers' that produce such expression or their environmental modulation, and in an ever increasing number of algae (see for example Giordano et al. 2005, Badger et al. 2006, Rost et al. 2008, Koch et al. 2013).

The validity of the methodological approach of utilizing the $\mathrm{pH}$ drift technique to investigate the extent of photosynthetic uptake of inorganic carbon species was confirmed since the publication of this work by a wide array of studies and applications, often in conjunction with other photosynthetic activity measurements and/or with a combination of specific inhibitors (Giordano et al. 2005, Raven et al. 2005, Chen et al. 2006, Mata et al. 2007, Maberly et al. 2009, Zou \& Gao 2009, Moulin et al. 2011, Zou et al. 2011, Cornwall et al. 2012). The $\mathrm{pH}$ drift technique has also been combined with measurements of $\delta^{13} \mathrm{C}$ (Kevekordes et al. 2006, Hepburn et al. 2011, Marconi et al. 2011), and with membrane inlet mass spectrometry (i.e. Maberly et al. 2009) to investigate the mechanisms and chemical form of DIC utilized by different algal species. Most recently some researchers used the $\mathrm{pH}$ drift in combination with other measures of photosynthetic rates under differing $\mathrm{pH}$ conditions and/or $\mathrm{CO}_{2}$ concentrations to evaluate 
the possible effects of ocean acidification due to anthropogenic increase of atmospheric $\mathrm{CO}_{2}$ on algal carbon acquisition (for example, Cornwall et al. 2012).

As of May 2013, the published article from which this dissertation is based upon has been cited 19 times (see Table 3 and the extended bibliography below). A few of the articles cite the published work for the methodological approaches used and corroborate their soundness (see for example Raven 2005, Kevekordes et al. 2006, Marconi et al. 2011), while Middleboe and Hansen (2007a and 2007b) though confirming their validity, raise some concerns related to the possible direct effects of the rising $\mathrm{pH}$ in the environment on the photosynthetic activity of the algae. All the articles (or dissertations) that cited the published work refer to the physiological patterns and characteristics of macroalgae as a function of habitat and DIC regimes experienced in each specific location. Interestingly, some articles investigated the ability to express a CCM under the prospect of ocean acidification due to the atmospheric anthropogenic increase of $\mathrm{CO}_{2}$ (Olischläger et al. 2012 and 2013, Roleda and Hurd 2012, Suárez-Álvarez et al. 2012); below I briefly discuss later this new direction in the field of research. Lastly, the evolutionary and ecological implications in the expression of CCMs and for which we raised important questions (see below) have also been recognized by others (Moulin et al. 2011).

While this work was not a ground breaking contribution for the intimate processes implicated in CCM - it was not our objective - it did confirm the general patterns of inorganic carbon acquisition found in coastal macroalgae, and the role of pertinent environmental variables in determining the vertical distribution of different physiologies. These patterns were previously made evident by many authors, starting as early as the 
1980s and with a very large body of research (see references in the main body of this work).

Most importantly the work presented in this thesis highlighted the necessity of deeper investigations relating to genetic and evolutionary aspects. Important questions were raised here, especially when considering the findings for Mastocarpus. Two arguments were provided in the present research as possible explanations for the pattern found in Mastocarpus: a process of acclimation to specific inorganic carbon regimen through the modulation of the CCMs activity, and/or the differential survivorship of specific genotypes with dissimilar abilities to express CCMs. The ability to use bicarbonate as a source of inorganic carbon can vary within the same species (Prins and Elzenga 1989, Menéndez et al. 2001, Badger et al. 2006), and carbon concentrating mechanisms can be induced under certain environmental conditions as a function of relative availability of $\mathrm{HCO}_{3}{ }^{-}$versus $\mathrm{CO}_{2}$ (Sand-Jensen and Gordon 1984, Surif and Raven 1990, Haglund and Pedersén 1992, Kübler and Raven 1994, Larsson and Axelsson 1999, Andría et al. 2001, Beardall and Giordano 2002, Zou et al. 2003, Giordano et al. 2005, Badger et al. 2006). Acclimation for carbon acquisition mechanisms has been found in a variety of taxa, microalgae and macroalgae, cyanobacteria and eukaryotes (for example Larsson et al. 1997, Axelsson et al. 1995 and 1999, Badger et al. 2006).

Mastocarpus in the upper fringe of the intertidal could be taking advantage of the prolonged exposure to air and responding to the higher $\mathrm{CO}_{2}$ availability due to gas exchanges with the atmosphere; in such environmental conditions the presence and activity of an external CA could be hypothesized as a mean to improve the gaseous 
exchanges between air and the thin layer of water surrounding the thallus, a mechanism postulated by Giordano and Maberly (1989) and Mercado and Niell (1999 and 2000).

The second possible explanation regarding the pattern exhibited by Mastocarpus would be the differential survival of specific genotypes; these specific genotypes would be able to express different carbon acquisition strategies, particularly suited for the environmental conditions experienced in the four collection sites, thus differentially surviving and outcompeting other less suited genotypes. This assumes that specimens of Mastocarpus papillatus collected along the vertical transect are part of the same species, and if true the population would be composed by two genetically and physiologically distinguishable groups, one inhabiting the highest fringe of the range and less efficient in scavenging the $\mathrm{HCO}_{3}{ }^{-}$from the medium, and the other found lower in the intertidal with more effective means of DIC acquisition under $\mathrm{CO}_{2}$ limitation.

If such genetic distinction were to be found for the locations in the present study, there is the possibility that the distinct and statistically significant dissimilarity found in DIC scavenging abilities between the uppermost and the lower specimens could indeed be related to genetic differences analogous to those described by Ludington et al. (2004). The main difference is that in the latter study the Mastocarpus was explicitly collected at the same tidal height in different locations where co-occurring, morphologically indistinguishable, and non-interbreeding groups were found, while regarding this research, it was along a vertical gradient that the species was investigated in order to relate inorganic carbon physiology to habitat. 
These intriguing aspects of Mastocarpus physiology and ecology still wait to be resolved and the argument could be expanded to a variety of other macroalgae that show a definite and broader vertical distribution.

According to http://www.algaebase.org (as of July 2013) there have been only a few recent changes in the taxonomy of the species included in the present work. These changes have been briefly mentioned in the prologue section of this thesis, and relate to 4 species formerly in the genus Porphyra and included in the present research. We included this genus to investigate the role of taxonomic relatedness on DIC carbon acquisition. The species $P$. papenfussii, $P$. perforata, $P$. torta, and $P$. fucicola were recently renamed and included in the genera Fuscifolium and Pyropia (see Table 1 for details, and Sutherland et al. 2011). These changes at the genus level did not invalidate the premises for the inclusion of the 4 species, as they still represented a closely related group in the family Bangiaceae. This group of macroalgae showed the only significant taxon-based effect on DIC acquisition strategies we were able to describe. We found no evidence of a significant relationship between taxonomy and DIC acquisition strategies in the other species included in the present research, all in the class Florideophyceae, perhaps only because of the very limited number of species that was possible to include in each taxonomic group (family or order).

Important aspects that were not analyzed in the present work relate to the importance of the thallus morphology and growth habit of the selected Rhodophyta species. Thallus morphology can have a drastic effect on the thickness and stability of the diffusion boundary layer through which important DIC exchanges occur. The diffusion boundary layer is also the space where important biochemical reactions take place, such 
as for example extCA-catalyzed reactions. The inorganic carbon diffusion rates through this layer are notably slow (Lobban and Harrison 1997), and any morphology that allows for a reduction of the layer would increase the rate of these exchanges between the bulk of the medium and the thallus (Hurd \& Pilditch 2011, Raven \& Hurd 2012). The degree of water movement experienced by the macroalgae could also influence the thickness of the boundary layer and as water movement increase over the thallus, the boundary layer decreases in thickness (Hannah \& Carpenter 2003, Raven \& Hurd 2012). Under these conditions the rate of photosynthesis has been found to increase, likely as a result of the increased DIC and/or $\mathrm{O}_{2}$ exchanges with the bulk of the surrounding medium (Raven \& Hurd 2012, and references therein).

Most of the latest research regarding algae and inorganic carbon acquisition mechanisms relates to the atmospheric anthropogenic increase of $\mathrm{CO}_{2}$ and the possible decreased $\mathrm{pH}$ of the oceans. Estimates of the ocean acidification suggest an oceanic $\mathrm{pH}$ of about 7.65 by 2100 , a phenomenon with potentially great ecological and evolutionary implications (see for example Rost et al. 2008, Hurd et al. 2009, Hepburn et al. 2011, Beerling 2012, Koch et al. 2013). The ocean acidification would result in a change of the relative concentrations of inorganic carbon species, potentially leading to ecological and evolutionary shifts in the photosynthetic arena of the oceans, an increase in dissolved $\mathrm{CO}_{2}$, a lesser increase in the concentration of $\mathrm{HCO}_{3}{ }^{-}$, and a decrease in $\mathrm{CO}_{3}{ }^{2-}$ (Feely et al. 2004, Cornwall et al. 2012).

Under current oceanic $\mathrm{pH}$ and inorganic carbon species concentrations, a good number of algae rely on $\mathrm{CCM}$, and utilize a great deal of $\mathrm{HCO}_{3}{ }^{-}$for their inorganic carbon photosynthetic needs. There is evidence that the increased availability of 
dissolved $\mathrm{CO}_{2}$ under ocean acidification triggers a considerable shift to dissolved $\mathrm{CO}_{2}$ utilization, likely due to the lower energetic expenses of the process as compared to the utilization of any CCM (Cornwall et al. 2012). The decrease in the expression or utilization of energetically costly CCMs could lead to higher biomass production in these algae (Cornwall et al. 2012, Xu and Gao 2012). Algae that do not express CCMs under today's conditions (most of the subtidal species in present work, but see also Raven et al. 2011) could also benefit from the increased available $\mathrm{CO}_{2}$ (Kubler et al. 1999, Cornwall et al. 2012). Calcifying algae, on the other hand, are not likely to profit from ocean acidification due to the inherent ecological disadvantages as compared to non-calcifying algae in an environment with lower $\mathrm{pH}$ and higher dissolved $\mathrm{CO}_{2}$ concentration (Cornwall et al. 2012, Hofmann et al. 2013).

Although somewhat differing from the main questions explored in my research, these studies bear a great deal of interest and can certain lead to further deepen our understanding of algal inorganic carbon acquisition, of the intimate details of their expressions and environmental modulation, in addition to the ecological relevance and the evolutionary implications under a possible change in the ocean carbon chemistry. 
Table 3. Citation Analysis Table: the following works cited the published article related to this dissertation. Citing articles are in chronological order. For full citations see the extended bibliography.

Raven et al., 2005, Can. J. Bot. 83: 879-890

Kevekordes et al., 2006, Phycologia, 45(4): 442-449

Mata et al., 2007, Journal of Phycology, 43: 1252-1258

Middelboe \& Hansen, 2007a, Marine Ecology Progress Series, 338: 107-117

Middelboe \& Hansen, 2007b, Marine Biology Research, 3(2): 134-144

Mata, 2008, Sapientia, Doctoral Dissertation,

Sampath-Wiley et al., 2008, Journal of Experimental Marine Biology and Ecology, 2(4): 83-91

Steyn, 2009, Free Web, Doctoral Dissertation,

Hepburn et al., 2011, Global Change Biology, 17: 2488-2497

Marconi et al., 2011, Journal of Phycology, 47: 1023-1035

Moulin et al., 2011, Aquatic Botany, 95(1): 31-38

Zou et al., 2011, Photosynthesis Research, 107(2): 159-168

Gomez \& Huovinen, 2012, Seaweed Biology Ecological Studies, 219: 25-46

Olischläger et al., 2012, Botanica Marina, 55(5): 511-525

Raven \& Hurd, 2012, Photosynthesis Research, 1(3): 105-125

Roleda \& Hurd, 2012, Seaweed Biology Ecological Studies, 219: 407-431

Suarez-Alvarez et al., 2012, Journal of Applied Phycology, 24(4): 815-823

Olischläger et al., 2013, Phycological Research, doi: 10.1111/pre.12006

Smith et al., 2013, Marine Biology, doi: 10.1007/s00227-013-2239-z 


\section{EXTENDED BIBLIOGRAPHY}

Andría, J. R., Brun, F. G., Pérez-Lloréns, J. L. \& Vergara, J. J. 2001. Acclimation responses of Gracilaria sp. (Rhodophyta) and Enteromorpha intestinalis (Chlorophyta) to changes in the external inorganic carbon concentration. Botanica Marina, 44:361-70.

Axelsson, L., Ryberg, H. \& Beer, S. 1995. Two modes of bicarbonate utilization in the marine green macroalga Ulva lactuca. Plant, Cell and Environment, 18:439-45.

Axelsson, L., Larsson, C. \& Ryberg, H. 1999. Affinity, capacity and oxygen sensitivity of two different mechanisms for bicarbonate utilization in Ulva lactuca L. (Chlorophyta). Plant, Cell and Environment, 22:969-78.

Badger, M. R., Price, G. D., Long, B. M. \& Woodger, F. J. 2006. The environmental plasticity and ecological genomics of the cyanobacterial $\mathrm{CO}_{2}$ concentrating mechanism. Journal of Experimental Botany, 57(2): 249-265.

Beardall, J. \& Giordano, M. 2002. Ecological implications of microalgal and cyanobacterial $\mathrm{CO}_{2}$ concentrating mechanisms, and their regulation. Functional Plant Biology, 29:335-347.

Beerling, D. J. 2012. Atmospheric carbon dioxide: a driver of photosynthetic eukaryote evolution for over a billion years? Philosophical Transactions of the Royal Society B, 367: 477-482.

Cornwall, C. E., Hepburn, C. D., Pritchard, D., Currie, K. I., McGraw, C. M., Hunter, K. A. \& Hurd, C. L. 2012. Carbon-use strategies in macroalgae: differential responses to lowered $\mathrm{pH}$ and implications for ocean acidification. Journal of Phycology, 48: 137-144.

Feely, R. A., Sabine, C. L., Lee, K., Berelson, W., Kelypas, J., Fabry, V. J. \& Millero, F. J. 2004. Impact of anthropogenic $\mathrm{CO}_{2}$ on the $\mathrm{CaCo}_{3}$ system in the oceans. Science, 305:362-366.

Giordano, M. \& Maberly, S. C. 1989. Distribution of carbonic anhydrase in British marine macroalgae. Oecologia, 81:534-9. 
Giordano, M., Beardall, J. \& Raven, J. A. 2005. $\mathrm{CO}_{2}$ Concentrating Mechanisms in Algae: Mechanisms, Environmental Modulation, and Evolution. Annual Review of Plant Biology, 56: 99-131.

Gómez, I. \& Huovinen, P. 2012. Morpho-functionality of Carbon Metabolism in Seaweeds. Seaweed Biology Ecological Studies, 219: 25-46

Haglund, K. \& Pedersén, M. 1992. Growth of the red alga Gracilaria tenuistipitata at high $\mathrm{pH}$. Influence of some environmental factors and correlation to an increased carbonic-anhydrase activity. Botanica Marina, 35: 579-87.

Hannah L. S. \& Carpenter, R. C. 2003. The effects of morphology and water flow on photosynthesis of marine macroalgae. Ecology, 84:2999-3012.

Hepburn, C. D., Pritchard, D. W., Cornwall, C. E., McLeod, R. J., Beardall, J., Raven, J. A. \& Hurd, C. L. 2011. Diversity of carbon use strategies in a kelp forest community: implications for a high $\mathrm{CO}_{2}$ ocean. Global Change Biology, 17: 2488-2497.

Hofmann, L. C., Straub, S. \& Bischof, K.. 2013. Elevated $\mathrm{CO}_{2}$ levels affect the activity of nitrate reductase and carbonic anhydrase in the calcifying rhodophyte Corallina officinalis. Journal of Experimental Botany, 64(4): 899-908.

Hurd, C. L. \& Pilditch, C. H. 2011. Flow-induced morphological variations affect diffusion boundary-layer thickness of Macrocystis pyrifera (Heterokontophyta, Laminariales). Journal of Phycology, 47(2): 341-351.

Hurd, C. L., Hepburn, C. D., Currie, K. I., Raven, J. A. \& Hunter, K. A. 2009. Testing the effects of ocean acidification on algal metabolism: considerations for experimental designs. Journal of Phycology, 45: 1236-1251.

Kevekordes, K., Holland, D., Häubner, N., Jenkins, S., Koss, R., Roberts, S., Raven J. A., Scrimgeour, C. M., Shelly, K., Stojkovic, S. \& Beardall, J. 2006. Inorganic carbon acquisition by eight species of Caulerpa (Caulerpaceae, Chlorophyta). Phycologia, 45(4): 442-449. 
Koch, M., Bowes, G., Ross, C. \& Zhang, X. 2013. Climate change and ocean acidification effects on seagrasses and marine macroalgae. Global Change Biology, 19: 103-132.

Kübler, J. E. \& Raven, J. A. 1994. Consequences of light limitation for carbon acquisition in three rhodophytes. Marine Ecology Progress Series, 110:203-9.

Kübler, J. E., Johnston, A. M. \& Raven, J. A. 1999. The effects of reduced and elevated $\mathrm{CO}_{2}$ and $\mathrm{O}_{2}$ on the seaweed Lomentaria articulata. Plant, Cell and Environment, 22:1303-1310.

Larsson, C. \& Axelsson, L. 1999. Bicarbonate uptake utilization in marine macroalgae. European Journal of Phycology, 34:79-86.

Larsson, C., Axelsson, L., Ryberg, H. \& Beer, S. 1997. Photosynthetic carbon utilization by Enteromorpha intestinalis (Chlorophyta) from a Swedish rockpool. European Journal of Phycology, 32:49-54.

Ludington, W. B., Callicott, K. A. \& DeTomaso, A. W. 2004. Genetic variation in Mastocarpus papillatus (Rhodophyta) in central California using amplified fragment length polymorphisms. Plant Species Biology, 19(2):107-13.

Maberly, S. C., Ball, L. A., Raven, J. A. \& Sültermeyer, D.. 2009. Inorganic carbon acquisition by Chrysophytes. Journal of Phycology 45:1052-1061.

Marconi, M., Giordano, M. \& J. A. Raven. 2011. Impact of taxonomy, geography, and depth on $\delta^{13} \mathrm{C}$ and $\delta^{15} \mathrm{~N}$ variation in a large collection of macroalgae. Journal of Phycology, 47: 1023-1035. doi: 10.1111/j.1529-8817.2011.01045.x

Mata, L., Silva, J., Schuenhoff, A. \& R. Santos. 2007. Is the tetrasporophyte of Asparagopsis armata (Bonnemaisoniales) limited by inorganic carbon in integrated aquaculture? Journal of Phycology, 43: 1252-1258.

Mata, L. 2008. Integrated aquaculture of Bonnemaisoniaceae: physiological and nutritional controls of biomass production and of halogenated metabolite content. Universidade do Algarve, Portugal, Doctoral Dissertation, Sapientia, Repositorio Institucional, http://hdl.handle.net/10400.1/1707 
Menéndez, M., Martínez, M. \& Comín, F. A. 2001. A comparative study of the effect of $\mathrm{pH}$ and inorganic carbon resources on the photosynthesis of three floating macroalgae species of a Mediterranean coastal lagoon. Journal of Experimental Marine Biology and Ecology, 256:123-36.

Mercado, J. M. \& Niell, F. X. 1999. Carbonic anhydrase activity and use of $\mathrm{HCO}_{3}{ }^{-}$in Bostrychia scorpioides (Ceramiales, Rhodophyceae). European Journal of Phycology, 34:13-9.

Mercado, J. M. \& Niell, F. X. 2000. Carbon dioxide uptake by Bostrychia scorpioides (Rhodophyceae) under emersed conditions. European Journal of Phycology, 35: 45-51.

Middelboe, A. L. \& Hansen, P. J. 2007a. High pH in shallow-water macroalgal habitats. Marine Ecology Progress Series, 338: 107-117.

Middelboe, A. L. \& Hansen, P. J. 2007b. Direct effects of $\mathrm{pH}$ and inorganic carbon on macroalgal photosynthesis and growth. Marine Biology Research, 3(2): 134-144.

Moulin, P., Andría, J. R., Axelsson, L. \& Mercado, J. M. 2011. Different mechanisms of inorganic carbon acquisition in red macroalgae (Rhodophyta) revealed by the use of TRIS buffer. Aquatic Botany, 95(1): 31-38.

Murray, R. B., Price, G. D., Long, B. M. \& Woodger, F. J. 2006. The environmental plasticity and ecological genomics of the cyanobacterial $\mathrm{CO}_{2}$ concentrating mechanism. Journal of Experimental Botany, 57(2): 249-265.

Olischläger, M., Bartsch, I., Gutow, L. \& Wiencke, C. 2012. Effects of ocean acidification on different life-cycle stages of the kelp Laminaria hyperborea (Phaeophyceae). Botanica Marina, 55(5): 511-525.

Olischläger, M., Bartsch, I., Gutow, L. \& Wiencke, C. 2013. Effects of ocean acidification on growth and physiology of Ulva lactuca (Chlorophyta) in a rockpoolscenario. Phycological Research, doi: 10.1111/pre.12006 
Prins, H. B. A. \& Elzenga, J. T. M. 1989. Bicarbonate utilization: function and mechanisms. Aquatic Botany, 34:59-83.

Raven, J. A. \& Hurd, C. L. 2012. Ecophysiology of photosynthesis in macroalgae. Photosynthesis Research, 1(3): 105-125.

Raven, J. A., Ball, L. A., Beardall, J., Giordano, M. \& Maberly, S. C. 2005. Algae lacking carbon-concentrating mechanisms. Canadian Journal of Botany 83: 879-890.

Roleda, M. Y. \& Hurd, C. L. 2012. Seaweed Responses to Ocean Acidification. Seaweed Biology Ecological Studies, 219: 407-431.

Rost B., Zondervan, I. \& Wolf-Gladrow, D. 2008. Sensitivity of phytoplankton to future changes in ocean carbonate chemistry: current knowledge, contradictions and research directions. Marine Ecology Progress Series, 373: 227-237.

Sampath-Wiley, P., Neefus, C. D. \& Jahnke, L. S. 2008. Seasonal effects of sun exposure and emersion on intertidal seaweed physiology: Fluctuations in antioxidant contents, photosynthetic pigments and photosynthetic efficiency in the red alga Porphyra umbilicalis Kützing (Rhodophyta, Bangiales). Journal of Experimental Marine Biology and Ecology, 2(4): 83-91.

Sand-Jensen, K. \& Gordon, D. M. 1984. Differential ability of marine and freshwater macrophytes to utilize $\mathrm{HCO}_{3}{ }^{-}$and $\mathrm{CO}_{2}$. Marine Biology, 80:247-53.

Smith, J. E., Price, N. N., Nelson, C. E. \& Haas, A. F.. 2013. Coupled changes in oxygen concentration and $\mathrm{pH}$ caused by metabolism of benthic coral reef organisms. Marine Biology, doi: 10.1007/s00227-013-2239-z

Steyn, P.-P. 2009. The ecophysiology of Gelidium pristoides (Turner) Kuetzing: towards commercial cultivation. Unpublished Doctoral Dissertation, Nelson Mandela Metropolitan University, South Africa. Retrieved from: http://nmmu.ac.za/

Suárez-Álvarez, S., Gómez-Pinchetti, J. L. \& García-Reina, G. 2012. Effects of increased $\mathrm{CO}_{2}$ levels on growth, photosynthesis, ammonium uptake and cell composition in the macroalga Hypnea spinella (Gigartinales, Rhodophyta). Journal of Applied Phycology, 24(4): 815-823. 
Surif, M. B. \& Raven, J. A. 1990. Photosynthetic gas exchange under emersed conditions in eulittoral and normally submersed members of the Fucales and the Laminariales: interpretation in relation to $\mathrm{C}$ isotope ratio and $\mathrm{N}$ and water use efficiency. Oecologia, 82:68-80.

Sutherland, J.E., Lindstrom, S.C., Nelson, W.A., Brodie, J., Lynch, M.D., Hwang, M.S., Choi, H.-G., Miyata, M., Kikuchi, N., Oliveira, M.C., Farr, T., Neefus, C., MolsMortensen, A. Milstein, D. \& Müller, K.M. 2011. A new look at an ancient order: generic revision of the Bangiales (Rhodophyta). Journal of Phycology, 47(5): 1131-1151.

$\mathrm{Xu}$, J. \& Gao, K. 2012. Future $\mathrm{CO}_{2}$-induced ocean acidification mediates the physiological performance of a green tide alga. Plant Physiology, 160:1762-1769.

Zou, D. \& Gao, K. 2009. Effects of elevated $\mathrm{CO}_{2}$ on the red seaweed Gracilaria lemaneiformis (Gigartinales, Rhodophyta) grown at different irradiance levels. Phycologia, 48(6): 510-517.

Zou, D., Gao, K. \& Xia, J. 2003. Photosynthetic utilization of inorganic carbon in the economic brown alga, Hizikia fusiforme, (Sargassaceae) from the South China Sea. Journal of Phycology, 39:1095-100.

Zou, D., Gao, K. \& Chen, W. 2011. Photosynthetic carbon acquisition in Sargassum henslowianum (Fucales, Phaeophyta), with special reference to the comparison between the vegetative and reproductive tissues. Photosynthesis Research, 107(2): 159-168 